\title{
Democracy, Foreign Direct Investment and Natural Resources*
}

\author{
Elizabeth Asiedu ${ }^{\dagger}$ \\ Department of Economics \\ University of Kansas
}

\author{
Donald Lien ${ }^{\ddagger}$ \\ Department of Economics \\ University of Texas, San Antonio
}

October 2010

\begin{abstract}
Existing studies assume that the impact of democracy on FDI is the same for resource exporting and non-resource exporting countries. This paper examines whether natural resources alter the relationship between FDI and democracy. We estimate a linear dynamic panel-data model using data from 112 developing countries over the period 1982-2007, and we find that there is some critical value of the share of minerals and oil in total exports below which democracy enhances FDI, and above which democracy reduces FDI. We identify 90 countries where an expansion of democracy may enhance FDI and 22 countries where an increase in democratization may reduce FDI.
\end{abstract}

JEL Classification: F23, D72.

Key Words: Democracy, Foreign Direct Investment, Natural Resources.

JEL Classification: F23, D72.

Please address all correspondence to:

Elizabeth Asiedu

Department of Economics, University of Kansas

Phone: 785-864-2843; Email: asiedu@ku.edu

\footnotetext{
*We are thankful to the editor Bruce Blonigen and three anonymous referees for detailed and valuable suggestions. We also thank Christobel Asiedu, Luisa Blanco, Francis Owusu and Yi Jin for helpful comments, and Peng Chen, Komla Dzigbede, and Kwasi Nti-Addae for excellent research assistance.

${ }^{\dagger}$ Department of Economics, University of Kansas, Lawrence, KS 66045. Phone: 785-864-2843, Email: asiedu@ku.edu

${ }_{\ddagger}^{\ddagger}$ Department of Economics, University of Texas, San Antonio, TX 78249. Phone: 210-458-7312, Email: don.lien@utsa.edu
} 


\section{Introduction}

In the past two decades, there has been a significant shift in the attitude towards foreign direct investment (FDI) to developing countries. Specifically, the discussion among academics and policymakers has shifted from whether FDI should be encouraged to how developing countries can attract FDI. Indeed many international development agencies, such as the World Bank, consider FDI as one of the most effective tools in the global fight against poverty, and therefore actively encourage poor countries to pursue policies that will enhance FDI flows. ${ }^{1}$ However, many of the countries that want to attract FDI also have weak democracies or nondemocratic governments. It is therefore important to understand the effect of democratization on FDI. For example, if democracy deters FDI, then countries face a trade off - between increased democratization and attracting more FDI.

This paper answers three questions: (i) Does democracy facilitate FDI?; (ii) Do natural resources alter the relationship between FDI and democracy?; and (iii) Do foreign direct investors prefer less democracy when they operate in natural resource exporting countries? Answers to these questions cannot be discerned from theory because the theoretical impact of democracy on FDI is unclear. $^{2}$ On the one hand, democratic institutions may have a positive effect on FDI because democracy provides checks and balances on elected officials, and this in turn reduces arbitrary government intervention, lowers the risk of policy reversal and strengthens property right protection (North and Weingast, 1989; Li 2009). ${ }^{3}$ On the other hand, multinational corporations (MNCs) may prefer to invest in autocratic countries. One reason is that unlike a democracy, autocratic governments are not accountable to their electorates. As a consequence, autocratic governments may be in a better position to provide more generous incentive packages and also offer protection from labor unions (Li and Resnick, 2003). In addition, it is easier for MNCs to exploit their oligopolistic or monopolistic positions when they operate in autocratic countries (Li and Resnick, 2003). Thus, the overall effect of democracy on FDI has to be determined empirically.

There is a vast empirical literature on the determinants of FDI, however, only a few of the studies include democracy as an explanatory variable. Our extensive literature review revealed that the empirical research on FDI and democracy is scant and also recent. We

\footnotetext{
${ }^{1}$ For example, the key function of the World Bank's Multilateral Investment Guarantees Agency (MIGA) is to facilitate FDI to poor countries. Also, the United Nations millennium declaration stipulates that an increase in FDI to developing countries will result in a significant reduction in global poverty rates.

${ }^{2} \mathrm{See} \mathrm{Li}$ and Resnick (2003) and Jensen (2003) for a detailed discussion about the theoretical impact of democracy on FDI.

${ }^{3}$ Due to the irreversible nature of FDI, the risk of policy reversal (e.g., changes in tax laws, royalty fees, etc) has a profound adverse impact on FDI. Li (2009) argues that democratic regimes are less likely to expropriate FDI than autocratic governments. He documents that between 1960 and 1990 there were 520 incidents of expropriation, and autocratic governments were responsible for about 423 of these incidents.
} 
found only twelve published articles which included democracy as a determinant of FDI, and only two of the papers were published before 2000. Eight of the studies found a positive and significant relationship between democracy and FDI, three found no significant effect, and only one study found a negative effect. ${ }^{4}$ The existing studies have several limitations. First, there is the issue of reverse causality: the relationship between FDI and democracy may be bidirectional. ${ }^{5}$ Second, the measure of democracy is likely to exhibit measurement errors. Third, there is the problem of an omitted variable bias. For example, only four papers included natural resources as an explanatory variable in their regressions. ${ }^{6}$ As we show in Section 5, natural resources has a causal effect on FDI. These three potential problems suggest that endogeneity may be a concern. Yet, none of the existing studies address this potential endogeneity problem. Another limitation is that most of the papers do not take into account the persistent nature of FDI. Furthermore, eleven out of the twelve papers employed ordinary least squares (OLS) or fixed effects (FE) estimations. One of the advantages of the FE estimator is that it mitigates some of the biases associated with OLS. However, the possible endogeneity of democracy, the short time periods of the panel data, and the persistent nature of FDI suggest that the FE estimator is likely to produce inconsistent and biased estimates. One more caveat of the existing literature is that all the studies assume that the effect of democracy on FDI is the same for resource exporting and non-resource exporting countries. This assumption seems inconsistent with the data.

Figures 1a-3b show the association between FDI and three measures of democracy for 87 developing countries. The democracy measures, free, polity and icrg are from three different sources: Freedom House, Polity IV and the International Country Risk Guide, respectively (we provide more details in Section 3 ). The countries are grouped according to their natural resource export intensity: Group 1 comprise of countries where the share of the sum of minerals and oil in total merchandise exports averaged over the period 1982-2007, denoted by $\overline{n a t}$, is less than $50 \%$, and Group 2 consist of countries where $\overline{n a t} \geq 50 \%$. For the

\footnotetext{
${ }^{4}$ Rodrik (1996), Harms and Ursprung (2002), Jensen (2003), Busse (2004), Jakobsen (2006), Jakobsen and de Soysa (2006), Adam and Filippaios (2007), and Busse and Hefeker (2007) found a positive effect; Li and Resnick (2003) found a negative effect; Oneal (1994), Alesina and Dollar (2000), and Buthe and Milner (2008) did not find a significant relationship between democracy and FDI. See Asiedu and Lien (2010) for a review of the literature.

${ }^{5} \mathrm{Li}$ and Reuveny (2003) find that FDI has a positive effect on democracy and Dutta and Roy (2009) find that FDI has a positive and significant effect on press freedom.

${ }^{6}$ The discussion of natural resources in these papers was cursory. Specifically, Jakobsen and de Soysa (2006) and Jakobsen (2006) reported that the estimated coefficient of the natural resource variable was not significant, and therefore did not include the natural resource variable in the estimations reported in the paper. Busse (2004) included natural resources in only one regression. Harms and Ursprung (2002) defined natural resource availability as a dummy that takes on value one if a country is a net exporter of oil throughout the 1990s and zero otherwise. Since natural resource is defined as a dummy variable, the variable was excluded in the fixed effects regressions.
} 
countries in Group 1, FDI seems to be positively associated with democracy for all the three measures of democracy (figures 1a, 2a and 3a). This contrasts with the Group 2 countries, where democracy seems to be negatively correlated with FDI (figure 3b) or uncorrelated with FDI (figures $1 \mathrm{~b}$ and $2 \mathrm{~b}$ ). Thus, the data suggest that foreign direct investors prefer democratic governments when they operate in non-resource exporting countries, but prefer less democratic or nondemocratic governments when they operate in resource exporting countries. The relevance of natural resources in determing the relationhsip between FDI and democracy is also consistent with the results of the 2007 global survey conducted by the Economist Intelligence Unit (EIU), where $44 \%$ of firms in extractive industries reported that democracy was important to their investment decisions, compared with $52 \%$ for all the firms surveyed (EIU, 2008).

This paper reassesses the relationship between democracy and FDI. We estimate a dynamic panel data model where we interact the measure of democracy with the share of the sum of minerals and fuel in total merchandise exports, nat. Our analyses utilize a panel data of 112 developing countries over the period 1982-2007. We employ three measures of democracy from three different sources and we utilize two estimation techniques - the dynamic panel "Difference" General Method of Moments (GMM) estimator proposed by Arellano and Bond (1991), and the "System" GMM estimator proposed by Blundell and Bond (1998). We find that there is some critical value of nat below which democracy enhances FDI, and above which democracy reduces FDI. We identify 90 countries where an expansion of democracy may enhance FDI, and 22 countries where an increase in democratization may reduce FDI. We disaggregate the measure of natural resources into its two components - fuel as a share of exports and minerals as a share of exports - and find that the relationship between FDI and democracy depends on the "size" and not the "type" of natural resources. Finally, we show that our results are robust: they hold for different estimation procedures, alternative measures of democracy, different sub-samples, different time periods, when we control for FDI risk, institutional quality, political risk, and when we take into account the endogeneity of natural resources and democracy. In all the regressions, we control for macroeconomic instability, market size, openness to trade and infrastructure development in host countries.

The paper contributes to the literature in two ways. First, to the best of our knowledge this is the first study to analyze the interaction effect of natural resources and democracy on FDI. Second, the estimation techniques that we employ ameliorate some of the econometric problems that plague previous studies. Specifically, the estimators account for unobserved country-specific effects, mitigate any potential endogeneity problems, permit the inclusion of lagged dependent variables as well as endogenous explanatory variables, and also accom- 
modate panel data with short time periods.

The remainder of the paper is organized as follows. Section 2 provides plausible reasons why natural resources may alter the relationship between FDI and democracy. Section 3 describes the data and the variables, Section 4 discusses the estimation procedure, Sections 5 and 6 present the empirical results, and Section 7 concludes.

\section{Why Natural Resources may alter the Relationship between Democracy and FDI}

We provide four plausible reasons. First, in most developing countries, investment restrictions and government intervention are more prevalent in extractive industries than in other industries. For example in Nigeria and Tanzania, 100\% foreign ownership is allowed in all sectors with the exception of the petroleum sector. When government regulations are extensive, it is more convenient for MNCs to operate under a political regime where power is more centralized and concentrated in the hands of one individual or a small group of individuals. ${ }^{7}$ Second, typically, regulations that cover FDI in extractive industries are fuzzy and the interpretation of the rules is at the discretion of top government officials. A good example is Botswana where taxation and government ownership share in diamond mining are subject to case-by-case negotiations, and the minister has power to remit or defer royalty on these investment. In such situations, a change in government effectively implies a change in a country's investment framework, which in turn implies an unstable policy environment. A stable policy environment is particularly important to MNCs in extractive industries because the exploration and extraction of minerals involve an initial large-scale capital intensive investment (i.e., sunk cost), a high degree of uncertainty and long gestation periods. ${ }^{8}$ Thus, to the extent that longevity of government implies a more stable and predictable business environment, democratic regimes are less preferable because democracies are typically associated with a frequent change of government officials. The view that autocratic regimes

\footnotetext{
${ }^{7}$ Consider an extreme case such as a dictatorship. Here, the MNC may need the approval of only one top government official in order to authenticate the firms' operations. Furthermore, if the MNC is successful in lobbying the official, the firms' efforts are almost guaranteed to produce results. In contrast, democratic institutions typically work on consensus, power is more diffused and the legislature is controlled by multiple groups. As a consequence, more resources and time are spent on lobbying efforts. Moreover, the outcome of the lobbying efforts is less predictable.

${ }^{8}$ The relative importance of a stable policy environment for MNCs in the primary sector is noted in the EIU (2008) survey. In the survey, MNCs in the primary sector indicated that "a stable and business-friendly environment" is the second (out of twelve) most important location criterion (the most important factor is access to natural resources). In contrast a stable policy environment ranked nine out of twelve for MNCs in manufacturing, and seven out of twelve for MNCs in the services sector. The two most important location factors for MNCs in services and manufacturing are the size of local markets and the growth of markets.
} 
provide a more stable business environment is consistent with the EIU survey results where about $62 \%$ of the respondents agreed with the statement that authoritarian regimes provide a more stable and predictable business environment. The third plausible explanation is that in many resource exporting countries, MNCs in extractive industries are prohibited from forming wholly-owned subsidiaries, and are often required to share ownership with the government (Asiedu and Esfahani, 2001). Naturally, an MNC will prefer to have a stable joint venture partner, and this is less likely to occur under a regime where the government in power changes every few years, such as in a democracy. Finally, we note that FDI in extractive industries is mainly driven by access to natural resources in host countries. However, natural resources are considered to be of strategic, political and financial importance to host countries and are therefore tightly controlled by the government. Thus, having close ties with the government may imply gaining access to an invaluable production input. Clearly, such relationships are easier to foster under autocratic regimes.

\section{The Data and the Variables}

Our empirical analyses utilize panel data of 112 developing countries over the period 19822007 (see the appendix for the list of countries). As it is standard in the literature, our dependent variable is net $F D I / G D P$ and we average the data over four years to smooth out cyclical fluctuations. The descriptive statistics of the variables is reported in Table1.

\subsection{Democracy}

There are many sources that provide ratings on the level of democratization in various countries. As expected, none of the measures of democracy is perfect. For example, Poe and Tate (1994) argue that the Freedom House data on civil and political liberties, which are one of the most utilized data in the profession, are biased in favor of Christian nations and Western democracies. Casper and Tufis (2003) also caution that different measures of democracy, even when highly correlated, may not be interchangeable because they may produce different results. Therefore in order to increase the credibility of our results, we employ three different measures of democracy from three different sources for our benchmark regressions.

The first measure of democracy, free, is derived from the data on political rights published by Freedom House. The data ranges from one to seven. A rating of one implies "there are competitive parties or other political groupings, the opposition plays an important role and has actual power" and a rating of seven indicates that political rights are absent. The second measure, polity, is derived from the democracy index published in Polity IV, and 
it reflects the openness and the competitiveness of the political process as well as the presence of institutions that allows political participation. The index ranges from zero to ten, where a higher rating implies higher levels of democracy. The third measure, icrg, is the measure of democracy published in the International Country Risk Guide (ICRG). The data are published by Political Risk Services, and it reflects the extent to which elections are free and fair, and the degree to which the government is accountable to its electorate. The data ranges from one to six, a higher score implies more democracy and accountability. To ease comparison between the different measures of democracy, we follow Acemoglu et al. (2008) and normalize free, polity and icrg to lie between zero and one, such that a higher number implies more democracy. The three measures of democracy vary in terms of coverage and availability. The regressions that employ free as a measure of democracy have up to 652 observations and covers 112 countries, polity has 614 observations and covers 102 countries, and $i \mathrm{crg}$ has 551 observations and it covers only 87 countries. The ICRG data are targeted toward foreign investors and as a consequence, the data are not available for many small or poor countries, or for countries that receive very little FDI. Furthermore, many of the countries in our sample for which the ICRG data is missing have high $F D I / G D P$ relative to the mean. This clearly generates a potential sample selection problem.

\subsection{Natural Resources}

We employ three measures of natural resources to capture a country's natural resource export intensity: (i) The share of fuel in total merchandise exports, fe; (ii) The share of minerals in total merchandise exports, me; and (iii) The share of fuel and minerals in total merchandise exports, nat, where nat $=m e+f e$. We use these measures for three reasons. First, they provide an indication of the type of FDI that goes to a country. For example, oil exporting countries are likely to have FDI concentrated in the oil sector. Second, the measures reflect the importance of natural resources to the host country. Such information is important in explaining our main result, that foreign direct investors may prefer less democracy in natural resource exporting countries. Third, the measures have been employed in several studies and also the data are readily available. ${ }^{9}$

We hypothesize a negative association between natural resources and FDI for the following three reasons. The first reason is based on the idea that resource booms lead to an appreciation of local currency. This makes the country's exports less competitive at world prices, and thereby crowds out investments in non-natural resource tradable sectors. If the crowding out is more than one-for-one, it may lead to an overall decline in FDI. The second

\footnotetext{
${ }^{9}$ Alternative measures of natural resources, for example measures that reflect natural resource abundance lack these three attributes.
} 
reason is that natural resources, in particular oil, are characterized by booms and busts, leading to increased volatility in the exchange rate (Sachs and Warner, 1995). In addition, a higher share of fuel and minerals in total merchandise exports implies less trade diversification, which in turn makes a country more vulnerable to external shocks. All these factors generate macroeconomic instability and therefore reduce FDI. Finally, FDI in natural resource rich countries tend to be concentrated in the natural resource sector. While natural resource exploration requires a large initial capital outlay, the continuing operations demand a small cash flow. Thus, after the initial phase, FDI may be staggered.

\subsection{Other Variables}

Control Variables: Following the literature on the determinants of FDI, we include the following variables in our regressions. We use trade/GDP as a measure of openness and the rate of inflation as a measure of macroeconomic uncertainty. We employ two measures to capture the level of infrastructure development in host countries: (i) the number of telephones per 100 population; and (ii) gross fixed capital formation as a share of GDP. ${ }^{10}$ All else equal, openness to trade, lower inflation and a better physical infrastructure should have a positive effect on FDI. Higher domestic incomes imply a greater demand for goods and services and therefore make the host country more attractive for FDI. Asiedu and Lien (2003) find that domestic income has to achieve a certain threshold in order to facilitate FDI flows. Thus, following Asiedu and Lien (2003), we include both GDP per capita and the square of GDP per capita in our regressions.

Robustness Variables: The robustness regressions employ data on measures of institutional quality, political instability and FDI risk in host countries. As pointed out in the introduction, democracies are generally associated with better institutions, such as private property protection and better enforcement of laws and regulations. Thus, it is possible that our measures of democracy are not capturing the "true" level of democratization in FDI host countries, but rather the measures are a proxy for the quality of institutions in these countries. If that is the case, then our results are driven by institutional quality and not by democracy. We attempt to capture the "pure" effect of democracy on FDI by controlling for institutional quality in host countries. We consider three measures of institutional quality which reflect (i) corruption (ii) the impartiality of the legal system; and (iii) bureaucratic quality in host countries. We also note that democracy does not necessarily imply political stability. For example, riots and assassinations can occur even in a democratic country

\footnotetext{
${ }^{10}$ Gross fixed capital formation includes funds spent on the construction of roads, railways, schools, commercial and industrial buildings and land improvements.
} 
(Bollen and Jackman, 1989). We consider two measures of political instability which reflect: (i) the level of internal and external conflict; and (ii) the stability of the government in power. Finally, we include a variable that captures the risk to investment as a result of "hostile" government actions (e.g., expropriation) and restrictions on FDI. We did not include these variables in our benchmark regressions because the data are from the ICRG and are available for a limited number of countries. Specifically, the number of countries drop from 112 to 87, and the number of observations decrease from 652 to 551.

\section{Estimation Procedure}

We estimate a linear dynamic panel-data (DPD) model to capture the effect of lagged FDI on current FDI. DPD models contain unobserved panel-level effects that are correlated with the lagged dependent variable, and this renders standard estimators inconsistent. The GMM estimator proposed by Arellano and Bond (1991) provides consistent estimates for such models. This estimator often referred to as the "difference" GMM estimator differences the data first and then uses lagged values of the endogenous variables as instruments. However, as pointed out by Arellano and Bover (1995), lagged levels are often poor instruments for first differences. Blundell and Bond (1998) proposed a more efficient estimator, the "system" GMM estimator, which mitigates the poor instruments problem by using additional moment conditions. However, the system estimator has one disadvantage: it utilizes too many instruments. Thus, the difference estimator suffers from the "weak" instruments problem and the system estimator exhibits the "too many" instruments problem (Hayakawa, 2007). Indeed, as shown by Acemoglu et al. (2005) and Bobba and Coviello (2007), the two estimation procedures can produce strikingly different results. ${ }^{11}$ Thus, in order to increase the credibility of our results, we report the estimations for both the difference and system estimators.

Now, the two estimation procedures assume that there is no autocorrelation in the idiosyncratic errors. Hence, for each regression, we test for autocorrelation and the validity of the instruments. Specifically, we report the p-values for the test for second order autocorrelation as well as the Hansen J test for overidentifying restrictions. These tests, however, lose power when the number of instruments, $i$, is large relative to the cross section sample size (in our case, the number of countries), $n$ - in particular when the instrument ratio, $r$, defined as $r=n / i<1$ (Roodman, 2007; Stata, 2009). Thus, when $r<1$, the assumptions underlying the two procedures may be violated. Furthermore, a lower $r$ raises the suscepti-

\footnotetext{
${ }^{11}$ Acemoglu et. al. (2005) used the Arellano and Bond difference estimator to show that education does not have a significant effect on democracy. However, Bobba and Coviello (2007) employed the Blundell and Bond system estimator and found that education has a significant and positive effect on democracy.
} 
bility of the estimates to a Type 1 error - i.e., producing significant results even though there is no underlying association between the variables involved (Roodman, 2007). The easiest solution to this problem is to reduce the instrument count by limiting the number of lagged levels to be included as instruments (Roodman, 2007; Stata, 2009). In all the 18 benchmark regressions and in 27 out of the 38 robustness regressions, $r \geq 1$, and therefore we do not restrict the number of lags of the dependent variable used for instrumentation. For the 11 cases where $r<1$, we limit the number of lagged levels to be included as instruments to the point where $r \geq 1$, and we check whether our results are robust to the reduction in instrument count.

We end the section by providing some details about our estimation strategy. ${ }^{12}$ First, we use the two-step GMM estimator, which is asymptotically efficient and robust to all kinds of heteroskedasticity. Second, the independent variables are treated as strictly exogenous in all the regressions, with the exception of four robustness regressions where democracy and natural resources are considered to be endogenous. Third, our regressions utilize only internal instruments - we do not include additional (external) instruments. Specifically, both the difference and system estimators use the first difference of all the exogenous variables as standard instruments, and the lags of the endogenous variables to generate the GMM-type instruments described in Arellano and Bond (1991). Furthermore, the system estimations include lagged differences of the endogenous variables as instruments for the level equation, but the difference estimations do not.

\section{Benchmark Regressions}

We estimate the equation:

$$
\begin{aligned}
f d i_{i t}= & \alpha d e m_{i t}+\gamma \text { nat }_{i t}+\beta n a t_{i t} \times d e m_{i t}+\rho f d i_{i t-1} \\
& +\Sigma_{j=1}^{J} \gamma_{j} Z_{j i t}+\theta_{i}+\varepsilon_{i t}
\end{aligned}
$$

where $i$ refers to countries, $t$ to time, $\theta_{i}$ is the country-specific effect, $f d i$ is net $F D I / G D P$, dem is a measure of democracy, nat is a measure of natural resource export intensity, nat $\times$ dem is the interaction term, and $Z$ is a vector of control variables.

\section{(i) Does democracy have a direct effect on FDI?}

To answer this question we estimate equation (1) without the interaction term, nat $\times$ dem. The parameter of interest is the coefficient of $d e m, \alpha$. The results are reported in Table 2. Note that $\widehat{\alpha}$ is positive and significant at the $1 \%$ level in all the regressions, suggesting that

\footnotetext{
${ }^{12}$ We used Stata 10 for our regressions. The discussion below draws heavily from Stata (2009).
} 
all else equal, democracy facilitates FDI flows. We use an example to illustrate the positive effect of democracy on FDI. Consider two countries in the same sub-region in SSA that have extremely different levels of democratization - Swaziland, the least democratic country in Southern Africa and Mauritius, the country with the highest democracy score. Then the regressions that employ the measure of democracy, free, shows that an improvement in democracy from the level of Swaziland $($ free $=0.06)$ to the level of Mauritius ( free $=0.98$ ) will increase $f d i$ by about 1.49 percentage points for the difference regression $[\partial f d i / \partial d e m=$ $1.616 \times(0.98-0.06) \approx 1.49]$ and about 0.94 percentage points for the system regression $[\partial f d i / \partial d e m=1.020 \times(0.98-0.06) \approx 0.94]$. The increase in $f d i$ is economically important because the average annual increase in $f d i$ to Swaziland, over the period 1984-2007 was about 0.28 percentage points.

We now turn our attention to the other variables. Natural resource export intensity has an adverse effect on FDI; openness to trade, good infrastructure and less inflation promote FDI; and GDP per capita has a positive impact on FDI only if income per capita exceeds a certain threshold. The estimated coefficient of lagged $f d i, \widehat{\rho}$, is negative, suggesting that current $f d i$ is negatively correlated with future $f d i$. Note that a one unit increase in the level of current democracy on current $f d i$ is equal to $\widehat{\alpha}$, and the long run effect on $f d i$ is

$\frac{\widehat{\alpha}}{1-\widehat{\rho}}$. Since $\widehat{\alpha}>\frac{\widehat{\alpha}}{1-\widehat{\rho}}$, this result implies that past levels of democratization has an impact on current and future $f d i$ flows, however, the effect subsides over time.

(ii) Do natural resources undermine the positive effect of democracy on FDI?

We estimate equation (1). Now, $\partial f d i / \partial d e m=\alpha+\beta \times n a t$, and therefore the parameters of interest are $\alpha$ and $\beta$. To conserve on space we report only the values of $\widehat{\alpha}$ and $\widehat{\beta}$ in Table 3. The full estimation results are available in the supplementary file. In all the regressions, $\widehat{\alpha}>0$ and significant at the $1 \%$ level, and $\widehat{\beta}<0$ and significant at the $1 \%$ level. This suggests natural resources significantly alter the relationship between FDI by reducing the positive effect of democracy on FDI. To elucidate our results, we evaluate the estimated value of $\partial f d i / \partial d e m$ at reasonable values of nat. Specifically, for each country, we calculate the average value of nat over the period 1982-2007, which we denote by $\overline{n a t}$, and evaluate $\partial \mathrm{fdi} / \partial \mathrm{dem}$ at the $10^{\text {th }}, 25^{\text {th }}, 50^{t h}, 75^{\text {th }}, 90^{\text {th }}$ percentile and the mean of $\overline{n a t}$. The $10^{\text {th }}, 25^{\text {th }}$, $50^{t h}, 75^{t h}, 90^{t h}$ percentile and the mean of $\overline{n a t}$ correspond to the average value of $n a t$ for Mauritius, Thailand, Ukraine, Indonesia, Syria and Belarus, respectively. The results are reported in Table 4 . Note that $\partial f d i / \partial d e m$ drops substantially as nat increases from the $10^{\text {th }}$ to the $75^{\text {th }}$ percentile of $\overline{n a t}$. For the difference GMM estimations, the decline in $\partial f d i / \partial d e m$ is about $83 \%$ for the regression using free, $82 \%$ for polity, and $81 \%$ for $i \mathrm{crg}$; and for the system estimations, $\partial f d i / \partial d e m$ decreases by about $83 \%, 82 \%$ and $81 \%$ for free, polity and $i c r g$, respectively. This indicates that natural resources drastically reduces the effectiveness 
of democracy in promoting FDI.

(iii) Can natural resources completely neutralize the positive effect of democracy on FDI?

As shown in Table 4, the estimated value of $\partial f d i / \partial d e m$ is positive and significant, up to the $75^{\text {th }}$ percentile of $\overline{n a t}$, suggesting that democracy has a positive effect on FDI for at least three quarters of the countries in the sample. However, the estimated value of $\partial f d i / \partial d e m$ loses significance or turns negative and significant when evaluated at the $90^{\text {th }}$ percentile of $\overline{n a t}$, an indication that for at least $10 \%$ of the countries in our sample, democracy has no significant effect on FDI or has a negative effect.

(iv) Which countries may benefit from an improvement in democratization and which countries may not?

To answer this question, we categorize our sample countries into two: Category A refer to countries where an expansion in democratic rights may promote FDI, and Category B comprise of countries where an increase in democracy may not result in an increase in FDI, and may possibly reduce FDI. We now attempt to identify the countries in the two categories. We first note that $\widehat{\alpha}>0$ and $\widehat{\beta}<0$, implying that there exists a critical value of nat, nat ${ }^{*}$, such that $\partial f d i / \partial d e m=\widehat{\alpha}+\widehat{\beta} \times n a t^{*}=0$. This implies that $\partial f d i / \partial d e m>0$ if and only if nat $<n a t^{*}$, suggesting that countries for which nat $<n a t^{*}$ fall in Category A and countries for which nat $\geq n a t^{*}$ fall in Category B. In classifying the countries, we compare each country's $\overline{n a t}$ (i.e., the value of nat averaged over the period 1982-2007) with nat*. Note that each of the six regressions will produce a different value of $n a t^{*} .{ }^{13}$ Our selection criteria is based on the median value of $n a t^{*}$, which is approximately equal to $52 \%$. Thus, countries for which $\overline{n a t}<52 \%$ fall in Category A and the remaining countries fall in Category B. There are 90 countries in Category A (about $80 \%$ of the countries in the sample) and 22 countries in Category B. Note that $\partial f d i / \partial d e m \leq 0$ for the Category B countries, suggesting that all else equal, foreign direct investors may prefer less democratic governments in these 22 countries. The countries are Algeria, Angola, Azerbaijan, Bolivia, Chile, Congo Republic, Gabon, Iran, Kazakhstan, Mongolia, Niger, Nigeria, Oman, Papua New Guinea, Peru, Russia, Seychelles, Syria, Trinidad, Venezuela, Yemen and Zambia. ${ }^{14}$

(v) Does the effect of democracy on FDI depend on the type of natural resource?

Recall that $n a t=f e+m e$, where $f e$ is the share of fuel in total merchandise exports and $m e$ is the share of metals and ore in total merchandise exports. Boschini et al. (2007)

\footnotetext{
${ }^{13}$ The values of $n a t^{*}$ for the difference regressions are 65, 50 and 56 for free, polity and icrg, respectively; and the values for the system regressions are 51,52 and 51, for free, polity and icrg, respectively.

${ }^{14} \mathrm{~A}$ word of caution is that the classification of the countries is not clear cut and is based on the GMM estimate of $n a t^{*}$, which is a random variable.
} 
find that different types of natural resources have different effects on economic growth. Thus, a question that comes to bear is whether the type of natural resources is relevant in determining the effect of democracy on FDI. For example, Zambia and Nigeria are resource intensive countries. However, Zambia's exports are concentrated in hard minerals (2\% oil and $87 \%$ minerals) whereas Nigeria's exports are mainly in oil (96\% oil and $0.03 \%$ minerals). Is the partial effect of democracy on FDI for these two countries statistically different? We re-estimate equation (1) where we use $f e$ and $m e$ as measures of natural resources, i.e.,

$$
\begin{aligned}
f d i_{i t}= & \rho f d i_{i, t-1}+\alpha d e m_{i t}+\gamma_{1} f e_{i t}+\gamma_{2} m e_{i t} \\
& +\beta_{1} f e_{i t} \times d e m_{i t}+\beta_{2} m e_{i t} \times d e m_{i t}+\Sigma_{j=1}^{J} \gamma_{j} Z_{j i t}+\theta_{i}+\varepsilon_{i t}
\end{aligned}
$$

Here, $\partial f d i / \partial d e m=\alpha+\beta_{1} \times f e+\beta_{2} \times m e$. The values of $\widehat{\alpha}, \widehat{\beta_{1}}$ and $\widehat{\beta_{2}}$ are reported in Table 5. Note that $\widehat{\alpha}$ is positive and significant at the $1 \%$ level, and $\widehat{\beta_{1}}$ and $\widehat{\beta_{2}}$ are negative and significant at the $1 \%$ level in all the regressions. This suggests that both oil and minerals undermine the positive effect of democracy on FDI. We now determine whether the interaction effect of democracy and natural resources on FDI is significantly different for fuel and minerals. Here, we test the hypothesis $H_{0}: \beta_{1}=\beta_{2}$. As shown in Table 5 , we refuse to reject $H_{0}$ in five out of the six regressions. Our results therefore suggest that overall, the type and the composition of resource intensity are not relevant in determining the interaction effect of democracy and natural resources on FDI.

\section{Robustness Regressions}

In order to have a reasonable sample size, the robustness estimations employ the measure of democracy that has the highest number of observations, i.e., free. Furthermore, to keep the discussion focused and also conserve on space, we report a summary of the results in Tables 6, 7 and 8. The full estimation results are available in the supplementary file. Below, we provide a brief discussion of the robustness estimations.

(i) Sub-samples: According to Blonigen and Wang (2005), the determinants of FDI to poor countries are different from the determinants of FDI to more developed economies. Asiedu (2002) also finds that the factors that drive FDI to Sub-Saharan Africa (SSA) are different from the factors that drive FDI to other developing countries. We therefore run separate regressions for middle income, low income, SSA and non-SSA countries. We also note that our results may be driven by the extensive political transformation that took place in Eastern Europe in the 1990s. We examine this hypothesis by running regressions where we exclude Transition countries. 
The number of countries for the middle income, low income and SSA samples are small, and as a consequence, the intrument ratio, $r<1$. For these samples, we check whether the result are robust to a reduction in instrument count, i.e., when we limit the instrument count such that $r>1$. In Panel A of Table 6, we report the values of $\widehat{\alpha}$ and $\widehat{\beta}$ for $r<1$ as well as $r>1$. Clearly, the results are robust: $\widehat{\alpha}$ and $\widehat{\beta}$ are significant at least at the $5 \%$ level in 14 out of the 16 regressions.

(ii) Different Time Periods: It is possible that our result is driven by the global expansion of democracy that began in the 1990s, in particular, after the collapse of the Soviet Union in 1991. To test this hypothesis, we split the sample into two sub-periods: 1982-1991 and 1992-2007. Now, we confined the benchmark regressions to the period 19822007 in order to facilitate comparison between the three measures of democracy. The reason is that the $i \mathrm{crg}$ data are not available prior to 1982. A relevant question is whether our results hold when we include data from the 1970s, i.e., the period 1970-2007. As shown in Panel B, $\widehat{\alpha}$ and $\widehat{\beta}$ are significant at the $1 \%$ level in all the six regressions.

(iii) Alternative Measures of Democracy: The definitions of free, polity and icrg are different, suggesting that the information in these indicators is not identical. However, the democracy variables are highly correlated and the coefficients are significant at the $1 \%$ level, suggesting that there is a high degree of commonality between the variables. ${ }^{15}$ We run a factor analysis on free, policy and icrg and use the principal component as a measure of democracy. We also compute the average of free, polity and icrg and use that as proxy for the overall level of democratization in the host country. Panel $\mathrm{C}$ shows that our results are robust to the alternative measures of democracy: $\widehat{\alpha}$ and $\widehat{\beta}$ are significant at the $1 \%$ level in all the four regressions.

(iv) Time Fixed Effects and Alternative Measure for the Dependent Variable: The benchmark regressions do not include time fixed effects. One reason for including time fixed effects is to expunge the effect of business cycles. However, including time dummies increases the number of instruments employed in the regressions, and this in turn weakens the reliability of the empirical results. As it is standard in the literature, we averaged the FDI data over four years to smooth out cyclical fluctuations. We however, test whether our results hold when we include time fixed effects.

Note that one could use FDI per capita as a dependent variable to analyze the effect of democracy on FDI flows. We used an alternative measure, FDI/GDP for the following reasons. First, the studies on the determinants of FDI typically employ FDI/GDP as dependent variable. Second, the data on $F D I / G D P$ has a wider coverage. For example

\footnotetext{
${ }^{15}$ The correlation coefficient, $\rho$, is $=0.89$ for free and polity, 0.68 for $i c r g$ and free, and 0.64 for polity and icrg.
} 
the number of observations drop by about 20\% (from 650 to 520) when we employ FDI per capita as dependent variable. We note that the effect of democracy on $F D I / G D P$ might reflect the impact of democracy on FDI, on GDP or both FDI and GDP. Thus, we examine whether our results hold when we use FDI per capita as the dependent variable. Panel D shows that $\widehat{\alpha}$ and $\widehat{\beta}$ are significant at the $1 \%$ level in all the four regressions.

(v) FDI Risk, Quality of Institutions and Political Risk: The results are reported in Table 7. We considered two specifications. Specifically, we run regressions where we included the measures of FDI risk, institutional quality and Political Risk one at a time (Columns 1-3 and 5-7), and another where we included all the variables (Columns 4 and 8). The results are robust: $\widehat{\alpha}$ is positive and significant at the $1 \%$ level and $\widehat{\beta}$ is negative and significant at the $1 \%$ level in all the regressions. In addition, the magnitudes of $\widehat{\alpha}$ and $\widehat{\beta}$ are fairly stable across specifications. With regards to the robustness variables, we found that overall, FDI risk, high levels of bureaucracy, and an ineffective legal system impede FDI flows. The effect of political instability on FDI is puzzling. Specifically, the estimated coefficient of the conflict variable, conflict, and the measure of instability of government, govstab, are significant at the $1 \%$ level in all the regressions, but have opposite signs: the coefficient of conflict is positive (wrong sign) and the coefficient of govstab is negative. The results persist even when conflict and govstab are included one at a time. Corruption did not display a consistent relationship with FDI.

(vi) Endogeneity of Democracy and Natural Resources: As pointed out in the introduction, democracy could be endogenous. Also, there is a potential endogeneity problem associated with our measure of natural resources. Specifically, it is possible that an unobserved variable may affect both FDI and exports. Since we measure natural resources as a share of exports, it is possible that our estimates are biased. The difference and the system estimators mitigate the endogeneity problem. However, in order to be thorough, we address this issue explicitly by specifying democracy and natural resources as endogenous variables in our regressions.

Note that if democracy is endogenous, then the interaction between democracy and natural resources is also endogenous. We consider two cases. In case 1, only democracy is treated as endogenous. Thus here, we re-estimate equation (1) where we specify dem and $n a t \times$ dem as endogenous variables. In case 2 , both democracy and natural resources are treated as endogenous and therefore the endogenous variables are dem, nat, and nat $\times$ dem. The results are reported in Table 8. As expected, the introduction of the endogenous variables increases the instrument count substantially, and as a consequence $r$ is low. ${ }^{16}$ Columns 1,2 ,

\footnotetext{
${ }^{16}$ For example the instrument count for the system GMM regressions increases from 82 for the case where nat and dem are exogenous (Column 4 of Table 3) to 295 when nat and dem are endogenous (Column 6 of
} 
5 and 6 show the results when the number of lags of the variables used in instrumentation is unrestricted and Columns 3, 4, 7 and 8 report the results when the number of instruments are curtailed. The results hold in both cases: $\widehat{\alpha}$ and $\widehat{\beta}$ are significant at the $1 \%$ level in all the eight regressions.

\section{Conclusion}

This paper has examined the interaction between democracy, natural resources and FDI. We find that the effect of democracy on FDI depends on the importance of natural resources in the host country's exports. Democracy facilitates FDI in countries where the share of natural resources in total exports is low, but has a negative effect on FDI in countries where exports are dominated by natural resources. This result has important implications for countries in Sub-Saharan Africa (SSA) - many of the countries in the region are in dire need of FDI (Asiedu, 2004), have weak democracies (Fosu, 2008), and their exports are dominated by primary commodities (Muehlbeger, 2007). ${ }^{17}$

\section{References}

[1] Acemoglu, Daron, Simon Johnson, James A. Robinson and Pierre Yared, 2005, "From Education to Democracy?," American Economic Review 95(2), 44-99.

[2] Acemoglu, Daron, Simon Johnson, James A. Robinson and Pierre Yared, 2008, "Income and Democracy," American Economic Review 98 (3), 808-842.

[3] Adam, Antonis and Fragkiskos Filippaios, 2007, "Foreign direct investment and civil liberties: A new perspective," European Journal of Political Economy 23(4), 1038-1052.

[4] Alesina, Alberto and David Dollar, 2000, "Who Gives Foreign Aid to Whom and Why?," Journal of Economic Growth 5(1), 33-63.

[5] Arellano, Manuel and Stephen Bond, 1991, "Some Tests of Specification for Panel Data: Monte Carlo Evidence and an Application to Employment Equations," Review of Economic Studies 58, 277-297.

[6] Arellano, Manuel and Olympia Bover, 1995, "Another Look at the Instrumental Variable Estimation of Error Component Models," Journal of Econometrics 68, 29-51.

[7] Asiedu, Elizabeth and Hadi Salehi Esfahani, 2001, "Ownership Structure in Foreign Direct Investment Projects," Review of Economics and Statistics 83 (4), 647-662.

[8] Asiedu, Elizabeth, 2002, "On the Determinants of Foreign Direct Investment to Developing Countries: Is Africa Different?," World Development 30 (1), 107-119.

\footnotetext{
Table 8).

${ }^{17}$ In about half of the countries in SSA, the share of primary commodity exports in total merchandise exports exceed $80 \%$ (Muehlbeger, 2007).
} 
[9] Asiedu, Elizabeth and Donald Lien, 2003, "Capital Controls and Foreign Direct Investment," World Development, 32 (3), 479-490.

[10] Asiedu, Elizabeth and Kwabena Gyimah-Brempong, 2008, "The Impact of Trade and Investment Liberalization on Foreign Direct Investment, Wages and Employment in Sub-Saharan Africa," African Development Review, 20 (1), 49-66.

[11] Asiedu, Elizabeth and Donald Lien, 2010, "Democracy, Foreign Direct Investment and Natural Resources," University of Kansas Working Paper.

[12] Blonigen, Bruce and Miao Wang, 2005, "Inappropriate Pooling of Wealthy and Poor Countries in Empirical FDI Studies," in Theordore Moran, Edward Graham and Magnus Blomstrom, ed., Washington DC: Institute for International Economics, 221-224.

[13] Blundell, Richard and Stephen Roy Bond, 1998, "Initial Conditions and Moment Restrictions in Dynamic Panel Data Models," Journal of Econometrics 87, 115-144.

[14] Bobba, Matteo and Decio Coviello, 2007, "Weak Instruments and Weak Identification, in Estimating the Effects of Education, on Democracy," Economics Letters 96(3), 301306.

[15] Bollen, K.A. and Robert Jackman, 1989, "Democracy, Stability and Dichotomies," American Sociological Review 54, 612-621.

[16] Boschini, Anne, D., Jan Pettersson and Jesper Roine, 2007, "Resource Curse or Not: A Question of Appropriability," Scandinavian Journal of Economics 109(3), 593-617.

[17] Busse, Matthias, 2004, "Transnational Corporations and Repression of Political Rights and Civil Liberties: An Empirical Analysis," Kyklos 57(1), 45-66.

[18] Busse, Matthias and Carsten Hefeker, 2007, "Political risk, institutions and foreign direct investment," European Journal of Political Economy 23(2), 397-415.

[19] Büthe, Tim and Helen V. Milner, 2008, "The Politics of Foreign Direct Investment into Developing Countries: Increasing FDI through International Trade Agreements?," American Journal of Political Science 52(4), 741-762.

[20] Casper, Gretchen and Claudiu Tufis, 2003, "Correlation versus Interchangeability: the Limited Robustness of Empirical Finding on Democracy Using Highly Correlated Data Sets," Political Analysis 11, 196-203.

[21] Dutta, Nabamita and Sanjukta Roy, 2009, "The Impact of Foreign Direct Investment on Press Freedom," Kyklos 62, 239-257.

[22] EIU, 2008, "World Investment Prospects to 2011: Foreign Direct Investment and the Challenge of Political Risk," Economist Intelligence Unit, New York.

[23] Hayakawa, Kazuhiko, 2007, "Small Sample Bias Properties of the System GMM Estimator in Dynamic Panel Data Models," Economics Letters 95(1), 32-38.

[24] Harms, Philipp and Heinrich W. Ursprung, 2002, "Do Civil and Political Repression Really Boost Foreign Direct Investment?" Economic Inquiry 40 (4), 651-663.

[25] Jakobsen, Jo, 2006, "Does democracy moderate the obsolete bargaining mechanism? an empirical analysis, 1983-2001," Transnational Corporations 15(3), 67-106. 
[26] Jakobsen, Jo and Indra de Soysa, 2006, "Do Foreign Investors Punish Democracy? Theory and Empirics, 1984-2001", Kyklos 59(3), 383-410.

[27] Jensen, Nathan, 2003, "Democratic Governance and Multinational Corporations: Political Regimes and Inflows of Foreign Direct Investment," International Organization $57(3), 587-616$.

[28] IPR, 2009, "Investment Policy Review (Several Issues)," United Nations Center for Trade and Development, New York: United Nations Publication.

[29] Li, Quan, 2009, "Democracy, Autocracy, and Expropriation of Foreign Direct Investment," Comparative Political Studies 42(8), 1098-1127.

[30] Li, Quan and Adam Resnick, 2003, "Reversal of Fortunes: Democratic Institutions and FDI Inflows to Developing Countries," International Organization 57, 175-211.

[31] Li, Quan, and Rafael Reuveny, 2003, "Economic globalization and democracy:An empirical analysis," British Journal of Political Science 33, 29-54.

[32] North, Douglass C. and Barry R. Weingast, 1989, "Constitutions and Commitment: The Evolution of Institutions Governing Public Choice in Seventeenth-Century England," Journal of Economic History 49(4), 803-32.

[33] Fosu, Augustin, 2008, "Democracy and Growth in Africa: Implications of Increasing Electoral Competitiveness," Economics Letters 100, 442-444.

[34] Oneal, John R, 1994, "The Affinity of Foreign Investors for Authoritarian Regimes." Political Research Quarterly 47, 565-88.

[35] Poe, Steven and Neal Tate, 1994, "Repression of Human Rights to Personal Integrity in the 1980s: A Global Analysis," American Political Science Review 88(4), 853-872.

[36] Roodman, David, 2007, "A Short Note on the Theme of Too Many Instruments," Center for Global Development Working Paper 125.

[37] Rodrik, Dani, 1996, "Labor Standards in International Trade: Do They Matter and What Do We Do About Them?" In Robert Lawrence, Dani Rodrik and John Whalley (eds.), Emerging Agenda For Global Trade: High States for Developing Countries, Baltimore:Johns Hopkins University Press, 35-79.

[38] Sachs, Jeffrey D., and Andrew M. Warner, 1995, "Natural Resource Abundance and Economic Growth," NBER Working Paper Series, 5398, 1-47.

[39] Stata, 2009. Stata Longitudinal Data/Panel Data Reference Manual, Stata Press, College Station, TX: StataCorp LP.

[40] World Bank, 2009, "World Development Indicators," (CD-ROM). 


\section{Figures 1a and 1b. FDI and Freedom House Measure of Democracy (Free)}

Figure 1a: Non-natural Resource Exporting Countries (Group 1)

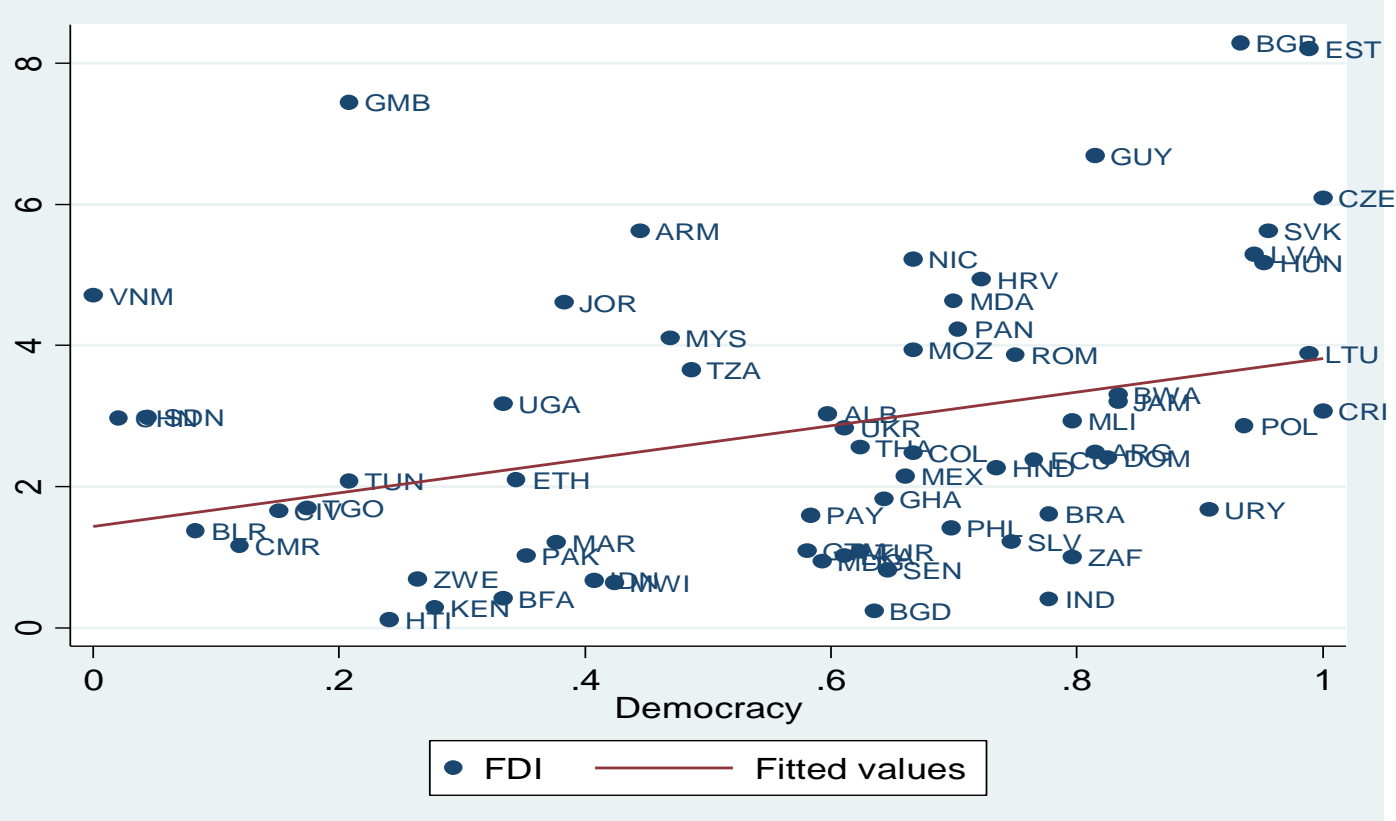

Figure 1b: Natural Resource Exporting Countries (Group 2)

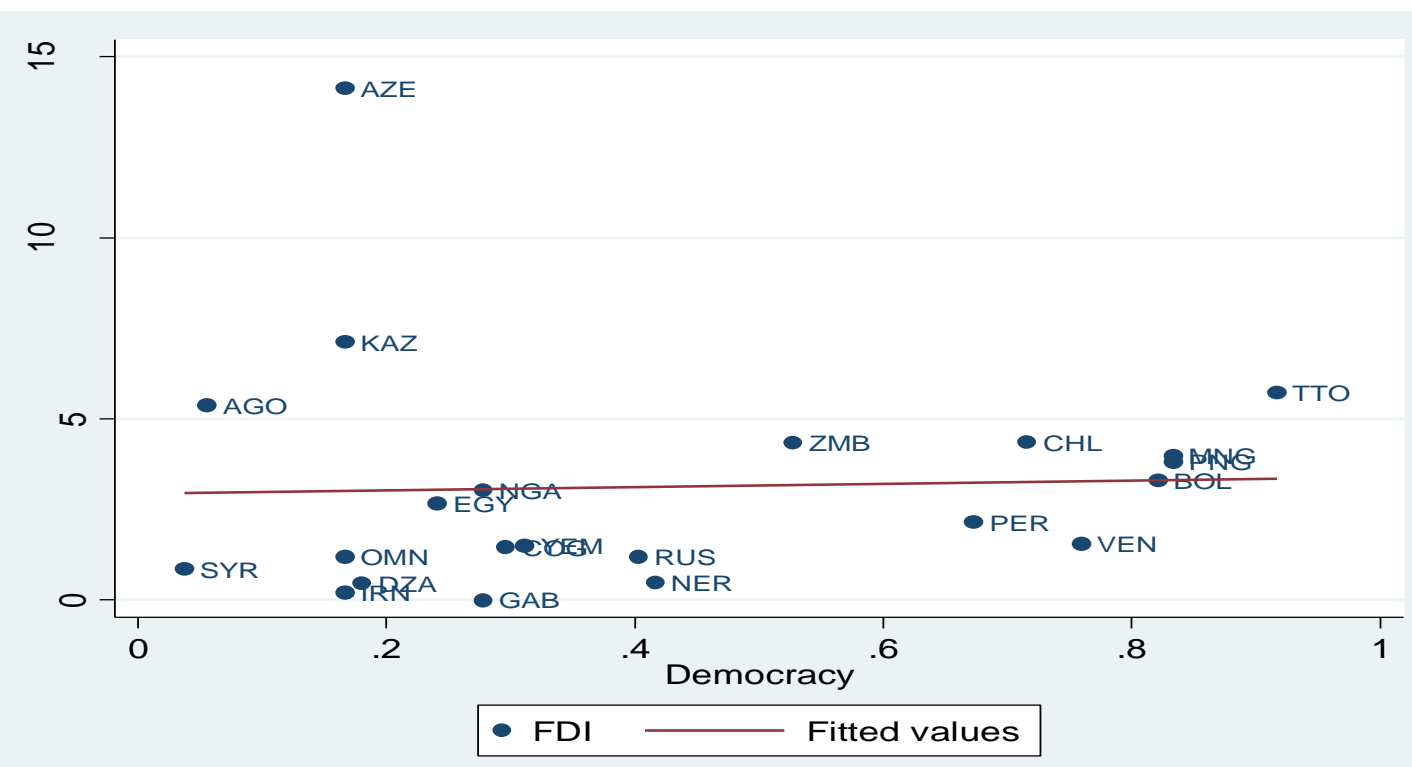

The data on FDI/GDP and democracy are averaged from 1982-2007. The democracy variable ranges from zero to 1, a higher number implies more democratic rights. Non-resource exporting countries (i.e. Group 1) comprise of countries where the sum of minerals and oil in total merchandise exports, $\overline{n a t}$, is less than $50 \%$ and resource exporting countries (i.e., Group 2) consists of countries where $\overline{n a t} \geq 50 \%$. There are 65 countries in Group 1 and 22 countries in Group 2. Democracy seems to be positively correlated with FDI/GDP for non-resource exporting countries (figure 1a), but uncorrelated for natural resource exporting countries (figure 1b). An OLS regression of democracy on FDI for Group 1 countries yielded, $\hat{y}=1.43+2.38 \times \mathrm{dem}$, with robust $\mathrm{p}$-value $=0.021$ and $R^{2}=0.11$; and for Group 2 countries, $\hat{y}=2.93+0.46 \times \mathrm{dem}$, robust $\mathrm{p}$-value $=0.842$ and $R^{2}=0.002$. See Table A1 in the appendix for the list of countries. 
Figures 2a and 2b. FDI and Polity IV Measure Democracy (Polity)

Figure 2a: Non-natural Resource Exporting Countries (Group 1)

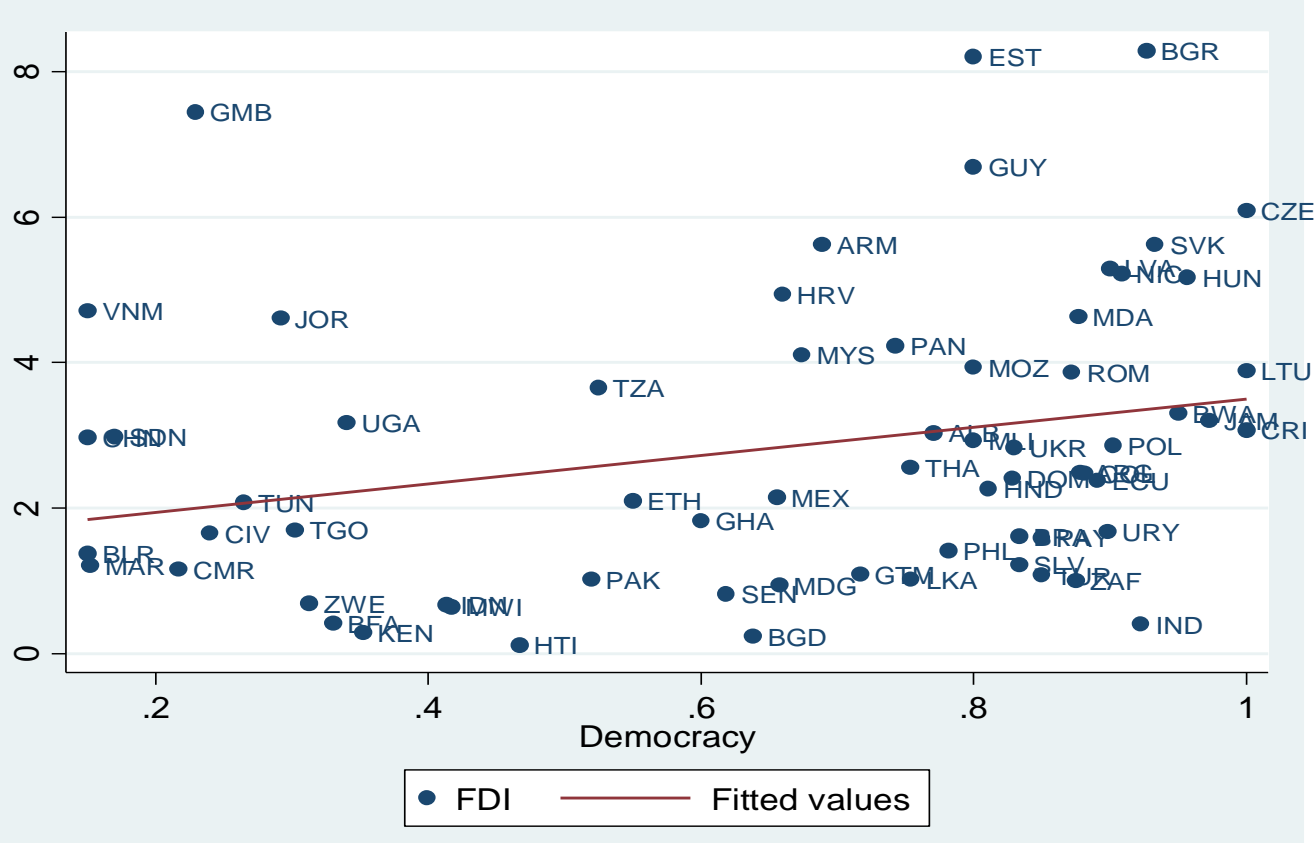

Figure 2b: Natural Resource Exporting Countries (Group 2)

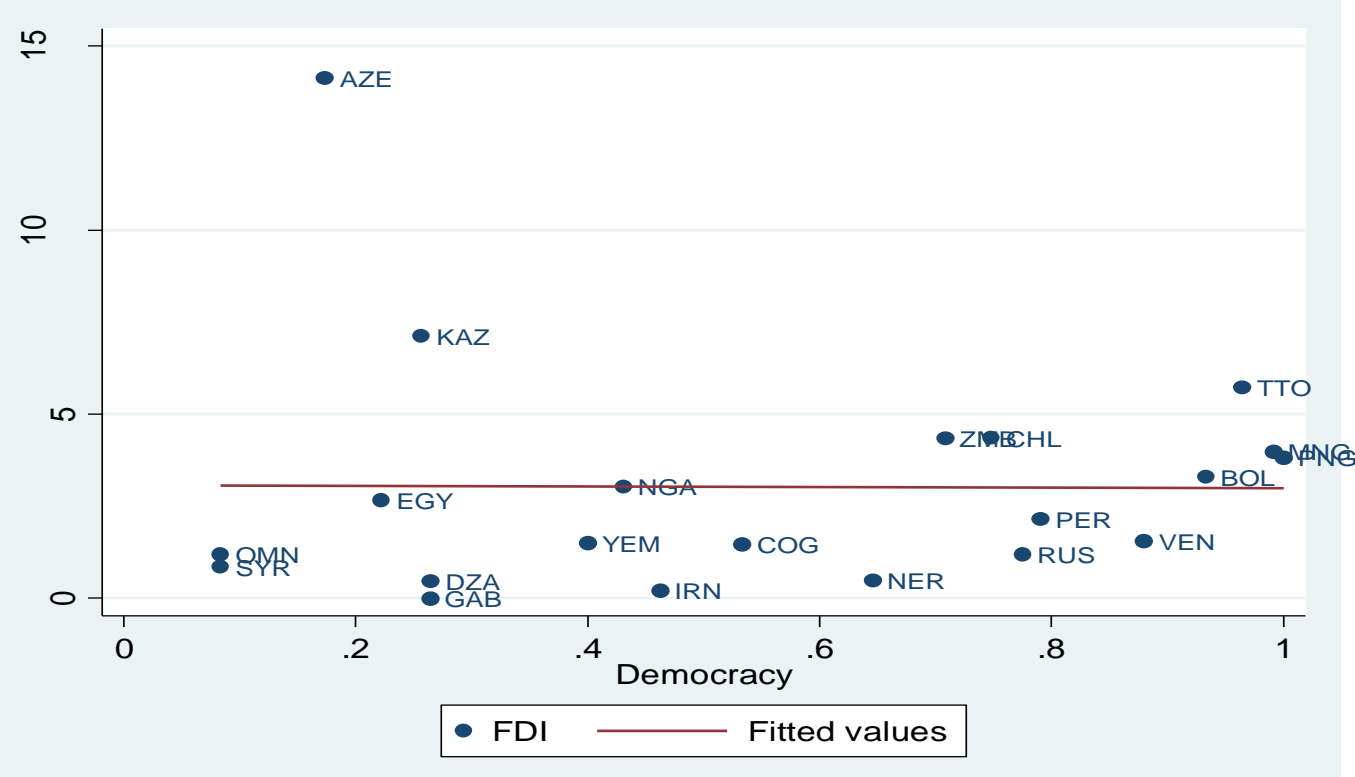

The data on FDI/GDP and democracy are averaged from 1982-2007. The democracy variable ranges from zero to 1, a higher number implies more democratic rights. Non-resource exporting countries (i.e. Group 1) comprise of countries where the sum of minerals and oil in total merchandise exports, $\overline{n a t}$, is less than $50 \%$ and resource exporting countries (i.e., Group 2) consists of countries where $\overline{n a t} \geq 50 \%$. There are 65 countries in Group 1 and 22 countries in Group 2. Democracy seems to be positively correlated with FDI/GDP for non-resource exporting countries (figure 2a), but uncorrelated for natural resource exporting countries (figure $2 b$ ). An OLS regression of democracy on FDI for Group 1 countries yielded, $\hat{y}=1.54+1.95 \times \mathrm{dem}$, with robust $\mathrm{p}$-value $=0.038$ and $R^{2}=0.07$; and for Group 2 countries, $\hat{y}=3.07-0.09 \times \mathrm{dem}$, robust $\mathrm{p}$-value $=0.972$ and $R^{2}=0.000$. See Table A1 in the appendix for the list of countries. 


\section{Figures 3a and 3b. FDI and ICRG Measure of Democracy (ICRG)}

\section{Figure 3a: Non-natural Resource Exporting Countries}

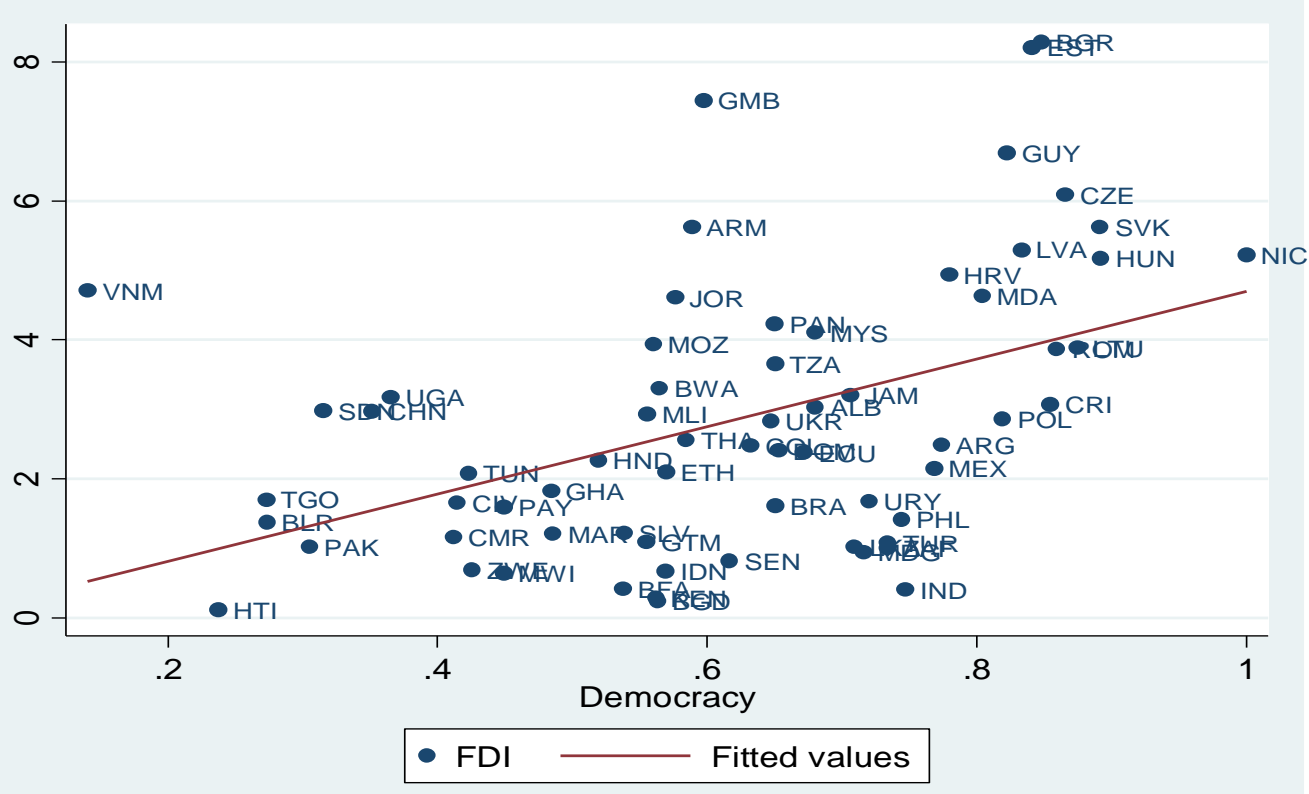

Figure 3b: Natural Resource Exporting Countries

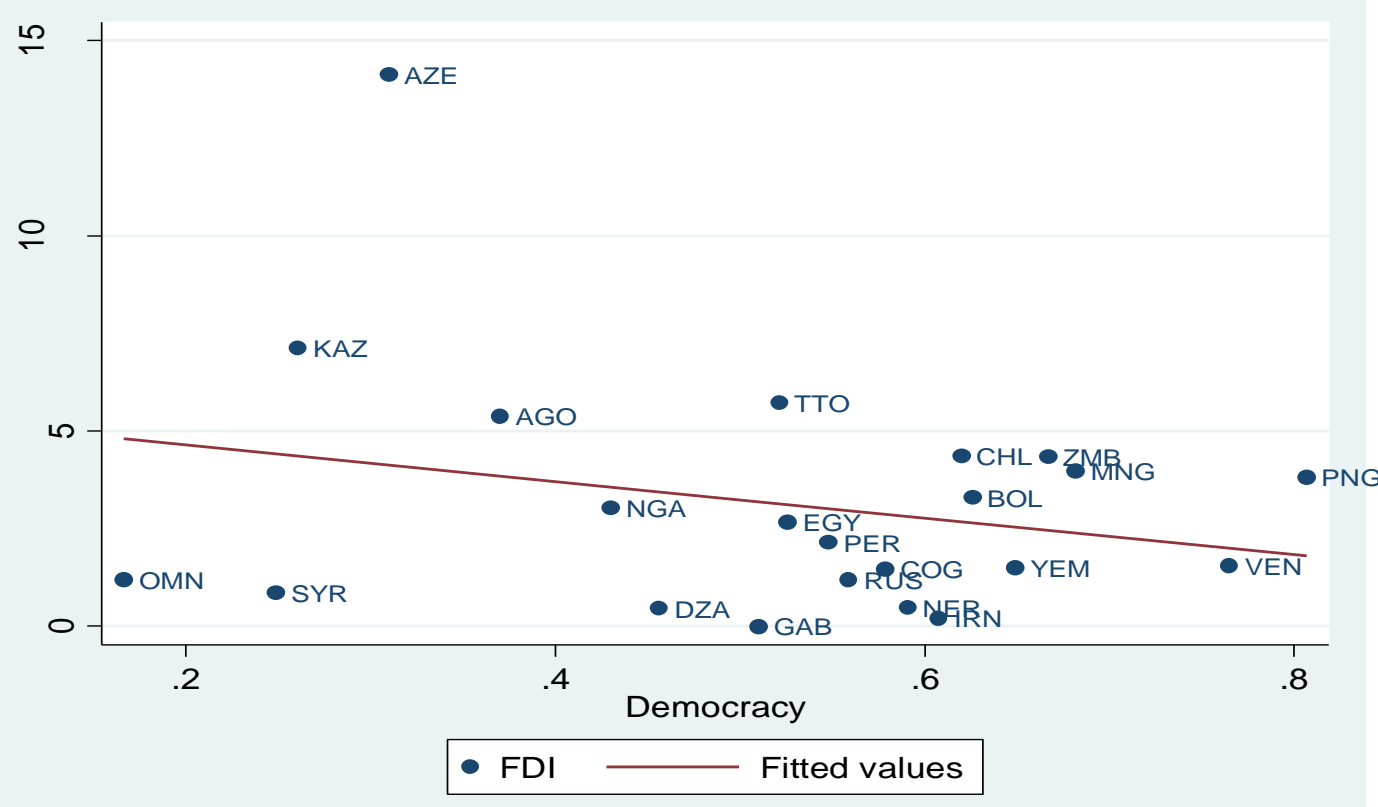

The data on FDI/GDP and democracy are averaged from 1982-2007. The democracy variable ranges from zero to 1, a higher number implies more democratic rights. Non-resource exporting countries (i.e. Group 1) comprise of countries where the sum of minerals and oil in total merchandise exports, $\overline{n a t}$, is less than $50 \%$ and resource exporting countries (i.e., Group 2) consists of countries where $\overline{n a t} \geq 50 \%$. There are 65 countries in Group 1 and 22 countries in Group 2. Democracy seems to be positively correlated with FDI/GDP for non-resource exporting countries (figure 3a), and negatively uncorrelated for natural resource exporting countries (figure 3b). An OLS regression of democracy on FDI for Group 1 yielded $\hat{y}=-0.16+4.86 \times d e m$, with robust $p$-value $=0.001$ and $R^{2}=0.21$; and for Group 2, $\hat{y}=5.57-4.68 \times \mathrm{dem}$, robust $\mathrm{p}$-value $=0.373$ and $R^{2}=0.062$. 
Table 1: Summary Statistics

\begin{tabular}{|c|c|c|c|c|c|c|c|c|c|c|c|c|}
\hline \multirow[t]{2}{*}{ Description } & \multicolumn{2}{|c|}{$\begin{array}{c}\text { Developing } \\
\text { Countries }\end{array}$} & \multicolumn{2}{|c|}{$\begin{array}{l}\text { Middle } \\
\text { Income }\end{array}$} & \multicolumn{2}{|c|}{$\begin{array}{c}\text { Low } \\
\text { Income }\end{array}$} & \multicolumn{2}{|c|}{$\begin{array}{l}\text { Sub-Saharan } \\
\text { Africa (SSA) }\end{array}$} & \multicolumn{2}{|c|}{$\begin{array}{l}\text { Outside } \\
\text { SSA }\end{array}$} & \multicolumn{2}{|c|}{$\begin{array}{c}\text { Non } \\
\text { Transition }\end{array}$} \\
\hline & Mean & Std. Dev & Mean & Std. Dev & Mean & Std. Dev & Mean & Std. Dev & Mean & Std. Dev & Mean & Std. Dev \\
\hline Free & 0.57 & 0.31 & 0.63 & 0.31 & 0.42 & 0.27 & 0.41 & 0.29 & 0.63 & 0.30 & 0.56 & 0.31 \\
\hline Polity & 0.63 & 0.32 & 0.69 & 0.31 & 0.51 & 0.30 & 0.49 & 0.30 & 0.69 & 0.31 & 0.62 & 0.32 \\
\hline Icrg & 0.60 & 0.22 & 0.63 & 0.21 & 0.52 & 0.21 & 0.51 & 0.17 & 0.62 & 0.22 & 0.58 & 0.21 \\
\hline FDI/GDP (\%) & 2.85 & 3.58 & 3.31 & 3.94 & 1.75 & 2.16 & 1.84 & 2.30 & 3.22 & 3.88 & 2.55 & 3.22 \\
\hline FDI per Capita & 5.10 & 14.11 & 7.37 & 16.89 & 0.64 & 0.95 & 1.54 & 5.54 & 6.75 & 16.40 & 4.88 & 14.30 \\
\hline Trade/GDP (\%) & 75.09 & 37.45 & 81.84 & 39.11 & 58.80 & 26.91 & 65.23 & 29.78 & 78.65 & 39.28 & 72.04 & 37.08 \\
\hline Investment/GDP (\%) & 21.19 & 6.46 & 22.37 & 6.37 & 18.36 & 5.77 & 18.27 & 5.66 & 22.25 & 6.40 & 20.97 & 6.51 \\
\hline Ln (1+ Phones $)$ & 1.80 & 1.09 & 2.30 & 0.87 & 0.60 & 0.47 & 0.73 & 0.72 & 2.19 & 0.94 & 1.63 & 1.04 \\
\hline Inflation $(\%)$ & 20.65 & 56.96 & 22.94 & 64.91 & 15.11 & 29.48 & 15.75 & 33.57 & 22.41 & 63.25 & 18.71 & 54.31 \\
\hline Ln (GDP per capita) & 7.10 & 1.09 & 7.66 & 0.73 & 5.76 & 0.45 & 6.12 & 1.01 & 7.46 & 0.87 & 7.03 & 1.10 \\
\hline Fuel/Exports (\%) & 16.67 & 26.49 & 19.05 & 27.36 & 23.40 & 27.84 & 16.15 & 28.86 & 16.86 & 25.61 & 16.45 & 27.07 \\
\hline Minerals/Exports (\%) & 8.35 & 14.67 & 6.64 & 11.14 & 10.94 & 23.36 & 11.60 & 19.15 & 7.17 & 12.49 & 8.64 & 15.50 \\
\hline Fuel \& Minerals/Exports (\%) & 25.02 & 28.14 & 25.68 & 28.27 & 12.47 & 20.31 & 27.75 & 30.81 & 24.03 & 27.08 & 25.08 & 28.81 \\
\hline Corruption & 0.56 & 0.16 & 0.55 & 0.15 & 0.60 & 0.15 & 0.59 & 0.16 & 0.56 & 0.15 & 0.57 & 0.15 \\
\hline Law and Order & 0.53 & 0.19 & 0.55 & 0.20 & 0.49 & 0.17 & 0.49 & 0.16 & 0.55 & 0.20 & 0.51 & 0.19 \\
\hline Bureaucracy & 0.55 & 0.22 & 0.52 & 0.21 & 0.62 & 0.22 & 0.62 & 0.23 & 0.52 & 0.21 & 0.55 & 0.22 \\
\hline FDI Risk & 0.52 & 0.17 & 0.50 & 0.17 & 0.56 & 0.15 & 0.54 & 0.15 & 0.51 & 0.17 & 0.53 & 0.16 \\
\hline Conflict & 0.25 & 0.16 & 0.23 & 0.16 & 0.28 & 0.15 & 0.27 & 0.14 & 0.24 & 0.16 & 0.26 & 0.16 \\
\hline Instability of Government & 0.37 & 0.18 & 0.37 & 0.17 & 0.38 & 0.19 & 0.37 & 0.18 & 0.37 & 0.17 & 0.38 & 0.18 \\
\hline
\end{tabular}

The democracy variables free, polity and icrg are from Freedom House, Polity IV and International Country Risk Guide (ICRG), respectively. The data are normalized to lie between zero and one, such that a higher number implies more democracy. FDI is the net inflows in current US\$, Trade is the sum of imports and exports, inflation is based on the annual CPI, investment/GDP is the share of gross fixed capital formation in GDP, phones is the number telephone lines per 100 people, GDP per capita is in constant 2000 US\$, fuel/exports is the share of fuel in total merchandize exports and minerals/exports is the share of minerals and ore in total merchandize exports. The data are from the World Development Indicators (2009), published by the World Bank. The data on institutions, FDI risk and political instability are from the ICRG. Corruption reflects the level of corruption within the political system, law and order measures the effectiveness of the rule of law, bureaucracy refers to the institutional strength and quality of the bureaucracy, FDI risk reflects the risk of expropriation and government constraints on profit repatriation, conflict is the average of internal conflict (such as political violence within the country) and external conflict (such as cross-border conflicts), and instability of government reflects the ability of government to stay in office. Similar to the democracy measures, the data are normalized to lie between zero and one, such that a higher number implies more corruption, better law enforcement, higher FDI risk and higher political instability. 


\begin{tabular}{|c|c|c|c|c|c|c|}
\hline \multirow[b]{3}{*}{ Variables } & \multicolumn{3}{|c|}{ Difference GMM } & \multicolumn{3}{|c|}{ System GMM } \\
\hline & $(1)$ & $(2)$ & $(3)$ & $(4)$ & $(5)$ & $(6)$ \\
\hline & Free & Polity & $\operatorname{Icr} g$ & Free & Polity & $I c r g$ \\
\hline \multirow[t]{2}{*}{ Democracy, $\operatorname{dem}(\widehat{\alpha})$} & $1.616^{* * *}$ & $1.189^{* * *}$ & $3.400 * * *$ & $1.020 * * *$ & $1.140^{* * *}$ & $3.012^{* * *}$ \\
\hline & $(0.000)$ & $(0.000)$ & $(0.000)$ & $(0.000)$ & $(0.000)$ & $(0.000)$ \\
\hline \multirow[t]{2}{*}{ Natural Resources, nat } & $-0.032^{* * *}$ & $-0.039 * * *$ & $-0.045 * * *$ & $-0.032^{* * *}$ & $-0.035^{* * *}$ & $-0.035 * * *$ \\
\hline & $(0.000)$ & $(0.000)$ & $(0.000)$ & $(0.000)$ & $(0.000)$ & $(0.000)$ \\
\hline \multirow[t]{2}{*}{ Lagged FDI/GDP } & $-0.251^{* * *}$ & $-0.171^{* * *}$ & $-0.184^{* * *}$ & $-0.076 * * *$ & -0.002 & $-0.075^{* * *}$ \\
\hline & $(0.000)$ & $(0.000)$ & $(0.000)$ & $(0.000)$ & $(0.771)$ & $(0.000)$ \\
\hline \multirow[t]{2}{*}{ Trade/GDP } & $0.023^{* * *}$ & $0.018^{* * *}$ & $0.015^{* * *}$ & $0.019^{* * *}$ & $0.008^{* * *}$ & $-0.011^{* * *}$ \\
\hline & $(0.000)$ & $(0.000)$ & $(0.000)$ & $(0.000)$ & $(0.000)$ & $(0.000)$ \\
\hline \multirow[t]{2}{*}{ Fixed Investment/GDP } & $0.237^{* * *}$ & $0.229^{* * *}$ & $0.221^{* * *}$ & $0.254^{* * *}$ & $0.255^{* * *}$ & $0.237^{* * *}$ \\
\hline & $(0.000)$ & $(0.000)$ & $(0.000)$ & $(0.000)$ & $(0.000)$ & $(0.000)$ \\
\hline \multirow[t]{2}{*}{ Ln (1+ Phones) } & $2.201^{* * *}$ & $1.834^{* * *}$ & $1.955^{* * *}$ & $2.643^{* * *}$ & $2.215^{* * *}$ & $2.486^{* * *}$ \\
\hline & $(0.000)$ & $(0.000)$ & $(0.000)$ & $(0.000)$ & $(0.000)$ & $(0.000)$ \\
\hline \multirow[t]{2}{*}{ Inflation } & $-0.005^{* * *}$ & $-0.004^{* * *}$ & $-0.003^{* * *}$ & $-0.004^{* * *}$ & $-0.003^{* * *}$ & -0.000 \\
\hline & $(0.000)$ & $(0.000)$ & $(0.000)$ & $(0.000)$ & $(0.000)$ & $(0.153)$ \\
\hline \multirow[t]{2}{*}{$\operatorname{lgdpc}=\operatorname{Ln}($ GDP per capita $)$} & $-5.439 * *$ & $-8.464^{* * *}$ & $-11.494^{* * *}$ & -1.961 & $-3.956 * * *$ & -1.456 \\
\hline & $(0.034)$ & $(0.000)$ & $(0.000)$ & $(0.181)$ & $(0.003)$ & $(0.186)$ \\
\hline \multirow[t]{2}{*}{$\operatorname{lgdpc} \times \operatorname{lgdpc}$} & 0.262 & $0.479^{* * *}$ & $0.646^{* * *}$ & -0.001 & $0.202^{* *}$ & 0.095 \\
\hline & $(0.114)$ & $(0.000)$ & $(0.000)$ & $(0.990)$ & $(0.021)$ & $(0.199)$ \\
\hline \multirow[t]{2}{*}{ Constant } & $17.456^{*}$ & $28.979 * * *$ & $41.129 * * *$ & 5.714 & $10.656^{* *}$ & -1.210 \\
\hline & $(0.074)$ & $(0.000)$ & $(0.000)$ & $(0.283)$ & $(0.027)$ & $(0.767)$ \\
\hline Hansen J Test (p-value $)^{1}$ & 0.338 & 0.424 & 0.376 & 0.369 & 0.311 & 0.651 \\
\hline Serial Correlation Test (p-value) ${ }^{2}$ & 0.662 & 0.527 & 0.909 & 0.493 & 0.477 & 0.407 \\
\hline Number of Observations & 566 & 541 & 455 & 652 & 614 & 551 \\
\hline Number of Countries, $n$ & 106 & 98 & 86 & 112 & 102 & 87 \\
\hline Number of Instruments, $i$ & 72 & 72 & 69 & 81 & 81 & 78 \\
\hline Instrument ratio, $r=n / i$ & 1.47 & 1.36 & 1.25 & 1.38 & 1.26 & 1.12 \\
\hline \multicolumn{7}{|l|}{ Limit the no.of lags of dependent } \\
\hline variable used in instrumentation? & No & No & No & No & No & No \\
\hline \multicolumn{7}{|c|}{ Notes: P-values in parenthesis. ${ }^{* * *} \mathrm{p}<0.01,{ }^{* *} \mathrm{p}<0.05,{ }^{*} \mathrm{p}<0.10$. Free, Polity and Icrg are measures of democracy from } \\
\hline \multicolumn{7}{|c|}{$\begin{array}{l}\text { Freedom House, Polity IV and The International Country Risk Guide, respectively. The data are normalized to lie between } \\
\text { zero and one. A higher number implies more democracy. }\end{array}$} \\
\hline
\end{tabular}


Table 3: The Interaction Effect of Democracy and Natural Resources on FDI

\begin{tabular}{|c|c|c|c|c|c|c|}
\hline \multirow[b]{2}{*}{ Variables } & \multicolumn{3}{|c|}{ Difference GMM } & \multicolumn{3}{|c|}{ System GMM } \\
\hline & $\begin{array}{c}(1) \\
\text { Free }\end{array}$ & $\begin{array}{c}(2) \\
\text { Polity }\end{array}$ & $\begin{array}{c}(3) \\
I c r g\end{array}$ & $\begin{array}{c}(4) \\
\text { Free }\end{array}$ & $\begin{array}{c}(5) \\
\text { Polity }\end{array}$ & $\begin{array}{c}(6) \\
I c r g\end{array}$ \\
\hline Democracy, dem, $\widehat{\alpha}$ & $\begin{array}{l}2.528 * * * \\
(0.000)\end{array}$ & $\begin{array}{l}2.048^{* * *} \\
(0.000)\end{array}$ & $\begin{array}{l}6.274 * * * \\
(0.000)\end{array}$ & $\begin{array}{l}2.205^{* * *} \\
(0.000)\end{array}$ & $\begin{array}{l}2.120^{* * *} \\
(0.000)\end{array}$ & $\begin{array}{l}5.813^{* * *} \\
(0.000)\end{array}$ \\
\hline nat $\times$ dem, $\widehat{\beta}$ & $\begin{array}{l}-0.039 * * * \\
(0.000)\end{array}$ & $\begin{array}{l}-0.041^{* * *} \\
(0.000)\end{array}$ & $\begin{array}{l}-0.112^{* * *} \\
(0.000)\end{array}$ & $\begin{array}{l}-0.043^{* * *} \\
(0.000)\end{array}$ & $\begin{array}{l}-0.041^{* * *} \\
(0.000)\end{array}$ & $\begin{array}{l}-0.113^{* * *} \\
(0.000)\end{array}$ \\
\hline Hansen $J$ Test (p-value $)^{1}$ & 0.320 & 0.511 & 0.239 & 0.414 & 0.350 & 0.650 \\
\hline Serial Correlation Test (p-value $)^{2}$ & 0.645 & 0.518 & 0.900 & 0.481 & 0.468 & 0.650 \\
\hline Number of Observations & 566 & 541 & 455 & 652 & 614 & 551 \\
\hline Number of Countries, $n$ & 106 & 98 & 86 & 112 & 102 & 87 \\
\hline Number of Instruments, $i$ & 73 & 73 & 70 & 82 & 82 & 79 \\
\hline Instrument ratio, $r=n / i$ & 1.45 & 1.34 & 1.23 & 1.37 & 1.17 & 1.10 \\
\hline
\end{tabular}

Table 4: $\partial f d i / \partial d e m=\widehat{\alpha}+\widehat{\beta} \times n a t$, Evaluated at various values of $n a t$

\begin{tabular}{|c|c|c|c|c|c|c|c|c|}
\hline \multirow[b]{2}{*}{$\begin{array}{l}\text { Value } \\
\text { of } n a t\end{array}$} & \multirow[b]{2}{*}{$\begin{array}{l}\text { Percentile } \\
\text { of } \overline{n a t}\end{array}$} & \multirow[b]{2}{*}{$\begin{array}{l}\text { Corresponding } \\
\text { Country }\end{array}$} & \multicolumn{3}{|c|}{ Difference GMM } & \multicolumn{3}{|c|}{ System GMM } \\
\hline & & & Free & Polity & $\operatorname{Icrg}$ & Free & Polity & Icrg \\
\hline 0.74 & $10^{t h}$ & Mauritius & $\begin{array}{c}2.499^{* * * *} \\
(0.000)\end{array}$ & $\begin{array}{c}2.018^{* * *} \\
(0.000)\end{array}$ & $\begin{array}{c}6.191^{* * *} \\
(0.000)\end{array}$ & $\begin{array}{c}2.173^{* * *} \\
(0.000)\end{array}$ & $\begin{array}{c}2.090^{* * *} \\
(0.000)\end{array}$ & $\begin{array}{c}5.213^{* * *} \\
(0.000)\end{array}$ \\
\hline 3.5 & $25^{t h}$ & Thailand & $\begin{array}{c}2.390 * * * \\
(0.000)\end{array}$ & $\begin{array}{c}1.906 * * * \\
(0.000)\end{array}$ & $\begin{array}{c}5.883^{* * *} \\
(0.000)\end{array}$ & $\begin{array}{c}2.054^{* * *} \\
(0.000)\end{array}$ & $\begin{array}{c}1.976^{* * *} \\
(0.000)\end{array}$ & $\begin{array}{c}5.417^{* * *} \\
(0.000)\end{array}$ \\
\hline 14.4 & $50^{t h}$ & Ukraine & $\begin{array}{c}1.961^{* * * *} \\
(0.000)\end{array}$ & $\begin{array}{c}1.464^{* * *} \\
(0.000)\end{array}$ & $\begin{array}{c}4.664^{* * *} \\
(0.000)\end{array}$ & $\begin{array}{c}1.582^{* * *} \\
(0.000)\end{array}$ & $\begin{array}{c}1.582^{* * *} \\
(0.000)\end{array}$ & $\begin{array}{c}4.184^{* * *} \\
(0.000)\end{array}$ \\
\hline 42.5 & $75^{t h}$ & Indonesia & $\begin{array}{c}0.855^{* * * *} \\
(0.000)\end{array}$ & $\begin{array}{l}0.325^{*} \\
(0.058)\end{array}$ & $\begin{array}{c}1.522^{* * *} \\
(0.000)\end{array}$ & $\begin{array}{c}0.365^{* * *} \\
(0.031)\end{array}$ & $\begin{array}{c}0.373^{* * *} \\
(0.000)\end{array}$ & $\begin{array}{c}1.007 * * * \\
(0.000)\end{array}$ \\
\hline 62.4 & $90^{t h}$ & Syria & $\begin{array}{c}0.072 \\
(0.833)\end{array}$ & $\begin{array}{c}-0.482^{*} \\
(0.081)\end{array}$ & $\begin{array}{l}-0.703 \\
(0.136)\end{array}$ & $\begin{array}{l}-0.500^{*} \\
(0.072)\end{array}$ & $\begin{array}{c}-0.445^{* * *} \\
(0.004)\end{array}$ & $\begin{array}{c}-1.243^{* * *} \\
(0.000)\end{array}$ \\
\hline 24.9 & Mean & Belarus & $\begin{array}{c}1.55^{* * *} \\
(0.000)\end{array}$ & $\begin{array}{c}1.037^{* * *} \\
(0.000)\end{array}$ & $\begin{array}{c}3.486^{* * *} \\
(0.000)\end{array}$ & $\begin{array}{c}1.126^{* * *} \\
(0.000)\end{array}$ & $\begin{array}{c}1.095^{* * *} \\
(0.000)\end{array}$ & $\begin{array}{c}2.994^{* * *} \\
(0.000)\end{array}$ \\
\hline
\end{tabular}

Notes: $n a t$ is the share of the sum of minerals and fuel in total exports (\%), and $\overline{n a t}$ is the average of nat, from $1982-2007$.

Table 5: The Interaction Effect of Fuel, Minerals and Democracy on FDI

\begin{tabular}{|c|c|c|c|c|c|c|}
\hline \multirow[b]{2}{*}{ Variables } & \multicolumn{3}{|c|}{ Difference GMM } & \multicolumn{3}{|c|}{ System GMM } \\
\hline & Free & Polity & Icrg & Free & Polity & Icrg \\
\hline \multirow[t]{2}{*}{ Democracy, dem, $\widehat{\alpha}$} & $2.657^{* * *}$ & $1.971^{* * *}$ & $6.008^{* * *}$ & $2.060^{* * *}$ & $2.115^{* * *}$ & $5.685^{* * *}$ \\
\hline & $(0.000)$ & $(0.000)$ & $(0.000)$ & $(0.000)$ & $(0.000)$ & $(0.000)$ \\
\hline \multirow[t]{2}{*}{$f e \times d e m, \widehat{\beta_{1}}$} & $-0.043^{* * *}$ & $-0.034^{* * *}$ & $-0.116^{* * *}$ & $-0.045^{* * *}$ & $-0.046^{* * *}$ & $-0.101^{* * *}$ \\
\hline & $(0.000)$ & $(0.000)$ & $(0.000)$ & $(0.000)$ & $(0.000)$ & $(0.000)$ \\
\hline \multirow[t]{2}{*}{$m e \times d e m, \widehat{\beta_{2}}$} & $-0.034^{* * *}$ & $-0.041^{* * *}$ & $-0.120^{* * *}$ & $-0.035^{* * *}$ & $-0.037 * * *$ & $-0.131^{* * *}$ \\
\hline & $(0.002)$ & $(0.000)$ & $(0.000)$ & $(0.000)$ & $(0.000)$ & $(0.000)$ \\
\hline$H_{o}: \beta_{1}=\beta_{2}$ (P-values) & 0.556 & 0.470 & 0.701 & 0.390 & 0.252 & 0.000 \\
\hline Reject $\mathrm{H}_{0}$ ? & No & No & No & No & No & Yes \\
\hline
\end{tabular}




\begin{tabular}{|c|c|c|c|c|}
\hline \multirow[b]{2}{*}{ Variables } & \multicolumn{2}{|c|}{ Difference GMM } & \multicolumn{2}{|c|}{ System GMM } \\
\hline & $\widehat{\alpha}$ & $\widehat{\beta}$ & $\widehat{\alpha}$ & $\widehat{\beta}$ \\
\hline \multicolumn{5}{|l|}{ Panel A: Sub-Samples } \\
\hline Middle Income Countries, $r<1$ & $\begin{array}{c}3.648^{* * *} \\
(0.000)\end{array}$ & $\begin{array}{c}-0.063^{* * *} \\
(0.003)\end{array}$ & $\begin{array}{c}3.315^{* * *} \\
(0.000)\end{array}$ & $\begin{array}{c}-0.063^{* * *} \\
(0.004)\end{array}$ \\
\hline Middle Income Countries, $r>1$ & $\begin{array}{c}2.620^{* * *} \\
(0.000)\end{array}$ & $\begin{array}{c}-0.026^{* * *} \\
(0.003)\end{array}$ & $\begin{array}{c}2.440 * * * \\
(0.000)\end{array}$ & $\begin{array}{c}-0.032^{* * *} \\
(0.004)\end{array}$ \\
\hline Low Income Countries, $r<1$ & $\begin{array}{c}1.035^{* * *} \\
(0.000)\end{array}$ & $\begin{array}{c}-0.053^{* * *} \\
(0.000)\end{array}$ & $\begin{array}{c}2.763^{* * *} \\
(0.000)\end{array}$ & $\begin{array}{c}-0.030 \\
(0.109)\end{array}$ \\
\hline Low Income Countries, $r>1$ & $\begin{array}{c}0.966^{* * *} \\
(0.000)\end{array}$ & $\begin{array}{c}-0.044^{* * *} \\
(0.000)\end{array}$ & $\begin{array}{c}2.051^{* * *} \\
(0.000)\end{array}$ & $\begin{array}{l}-0.010 \\
(0.109)\end{array}$ \\
\hline Sub-Saharan Africa (SSA), $r<1$ & $\begin{array}{c}-0.471 \\
(0.782)\end{array}$ & $\begin{array}{c}-0.031 \\
(0.112)\end{array}$ & $\begin{array}{c}2.744^{* * *} \\
(0.008)\end{array}$ & $\begin{array}{c}-0.078^{* * *} \\
(0.000)\end{array}$ \\
\hline Sub-Saharan Africa (SSA), $r>1$ & $\begin{array}{c}0.799^{* *} \\
(0.013)\end{array}$ & $\begin{array}{c}-0.056^{* * *} \\
(0.000)\end{array}$ & $\begin{array}{c}-0.082 \\
(0.831)\end{array}$ & $\begin{array}{c}-0.041^{* * *} \\
(0.000)\end{array}$ \\
\hline Non-SSA countries & $\begin{array}{c}3.052^{* * *} \\
(0.000)\end{array}$ & $\begin{array}{c}-0.019^{* * *} \\
(0.000)\end{array}$ & $\begin{array}{c}1.802^{* * *} \\
(0.000)\end{array}$ & $\begin{array}{c}-0.012^{* * *} \\
(0.009)\end{array}$ \\
\hline Exclude Transition Countries & $\begin{array}{c}2.697^{* * *} \\
(0.000)\end{array}$ & $\begin{array}{c}-0.054^{* * *} \\
(0.000)\end{array}$ & $\begin{array}{c}2.674^{* * *} \\
(0.000)\end{array}$ & $\begin{array}{c}-0.075 * * * \\
(0.000)\end{array}$ \\
\hline \multicolumn{5}{|l|}{ Panel B: Sub-Periods } \\
\hline $1982-1992$ & $\begin{array}{c}0.884^{* *} \\
(0.018)\end{array}$ & $\begin{array}{c}-0.035^{* * *} \\
(0.000)\end{array}$ & $\begin{array}{c}1.219^{* * *} \\
(0.003)\end{array}$ & $\begin{array}{c}-0.045^{* * *} \\
(0.000)\end{array}$ \\
\hline $1992-2007$ & $\begin{array}{c}2.631^{* * *} \\
(0.000)\end{array}$ & $\begin{array}{c}-0.034^{* * *} \\
(0.009)\end{array}$ & $\begin{array}{c}1.689^{* * *} \\
(0.000)\end{array}$ & $\begin{array}{c}-0.027^{* * *} \\
(0.008)\end{array}$ \\
\hline $1970-2007$ & $\begin{array}{c}2.463^{* * *} \\
(0.000)\end{array}$ & $\begin{array}{c}-0.050 * * * \\
(0.000)\end{array}$ & $\begin{array}{c}2.218^{* * *} \\
(0.000)\end{array}$ & $\begin{array}{c}-0.049 * * * \\
(0.000)\end{array}$ \\
\hline \multicolumn{5}{|c|}{ Panel C: Alternative Measures of Democracy } \\
\hline Principal Component & $\begin{array}{c}1.126^{* * *} \\
(0.000)\end{array}$ & $\begin{array}{c}-0.020 * * * \\
(0.000)\end{array}$ & $\begin{array}{c}1.152^{* * *} \\
(0.000)\end{array}$ & $\begin{array}{c}-0.019 * * * \\
(0.000)\end{array}$ \\
\hline Average Democracy & $\begin{array}{c}5.717^{* * *} \\
(0.000)\end{array}$ & $\begin{array}{c}-0.100 * * * \\
(0.000)\end{array}$ & $\begin{array}{c}5.848^{* * *} \\
(0.000)\end{array}$ & $\begin{array}{c}-0.097^{* * *} \\
(0.000)\end{array}$ \\
\hline \multicolumn{5}{|c|}{ Panel D: Time Fixed Effects \& Alternative Measure for Dependent Variab } \\
\hline Include Fixed Effects & $\begin{array}{c}2.128^{* * *} \\
(0.000)\end{array}$ & $\begin{array}{c}-0.032^{* * *} \\
(0.000)\end{array}$ & $\begin{array}{c}2.177^{* * *} \\
(0.000)\end{array}$ & $\begin{array}{c}-0.038^{* * *} \\
(0.000)\end{array}$ \\
\hline FDI per Capita & $\begin{array}{c}6.355^{* * *} \\
(0.000)\end{array}$ & $\begin{array}{c}-0.196 * * * \\
(0.000)\end{array}$ & $\begin{array}{c}7.130 * * * \\
(0.000)\end{array}$ & $\begin{array}{c}-0.207^{* * *} \\
(0.000)\end{array}$ \\
\hline
\end{tabular}


Table 7: Robustness Regressions. FDI Risk, Institutional Quality and Political Risk

\begin{tabular}{|c|c|c|c|c|c|c|c|c|}
\hline \multirow{5}{*}{ Variables } & \multicolumn{4}{|c|}{ Difference GMM } & \multicolumn{4}{|c|}{ System GMM } \\
\hline & (1) & $(2)$ & $(3)$ & (4) & (5) & (6) & $(7)$ & (8) \\
\hline & Include & Include & Include & Include & Include & Include & Include & Include \\
\hline & FDI & Institutional & Political & All & FDI & Institutional & Political & All \\
\hline & Risk & Quality & Risk & Variables & Risk & Quality & Risk & Variables \\
\hline dem, $\widehat{\alpha}$ & $3.572^{* * *}$ & $3.894^{* * *}$ & $3.816^{* * *}$ & $3.644^{* * *}$ & $3.784^{* * *}$ & $4.238^{* * *}$ & $4.272 * * *$ & $4.294^{* * *}$ \\
\hline & $(0.000)$ & $(0.000)$ & $(0.000)$ & $(0.000)$ & $(0.000)$ & $(0.000)$ & $\mathrm{v}$ & $(0.000)$ \\
\hline nat $\times$ dem, $\widehat{\beta}$ & $-0.068^{* * *}$ & $-0.070^{* * *}$ & $-0.075^{* * *}$ & $-0.070^{* * *}$ & $-0.070^{* * *}$ & $-0.077^{* * *}$ & $-0.082 * * *$ & $-0.083^{* * *}$ \\
\hline & $(0.000)$ & $(0.000)$ & $(0.000)$ & $(0.000)$ & $(0.000)$ & $(0.000)$ & $(0.000)$ & $(0.000)$ \\
\hline FDI Risk & $-3.523^{* * *}$ & & & $-2.203^{* * *}$ & $-1.857 * * *$ & & & $-1.023 * * *$ \\
\hline & $(0.000)$ & & & $(0.000)$ & $(0.000)$ & & & $(0.000)$ \\
\hline Corruption & & $0.974^{* * *}$ & & 0.064 & & -0.250 & & $-1.550^{* * *}$ \\
\hline & & $(0.004)$ & & $(0.855)$ & & $(0.245)$ & & $(0.000)$ \\
\hline Rule of Law & & $0.477^{* *}$ & & $0.541^{*}$ & & 0.098 & & $1.357 * * *$ \\
\hline & & $(0.044)$ & & $(0.067)$ & & $(0.644)$ & & $(0.000)$ \\
\hline Bureaucracy & & $-1.515^{* * *}$ & & $-1.639 * * *$ & & -0.195 & & $-0.490^{* *}$ \\
\hline & & $(0.000)$ & & $(0.000)$ & & $(0.198)$ & & $(0.014)$ \\
\hline Conflict & & & $0.811^{* * *}$ & $1.780 * * *$ & & & $2.507 * * *$ & $4.012^{* * *}$ \\
\hline & & & $(0.003)$ & $(0.000)$ & & & $(0.000)$ & $(0.000)$ \\
\hline Instability of Government & & & $-2.801 * * *$ & $-1.731^{* * *}$ & & & $-2.440 * * *$ & $-2.040^{* * *}$ \\
\hline & & & $(0.000)$ & $(0.000)$ & & & $(0.000)$ & $(0.000)$ \\
\hline Number of Observations & 455 & 455 & 455 & 455 & 551 & 551 & 551 & 551 \\
\hline Number of Countries, $n$ & 86 & 86 & 86 & 86 & 87 & 87 & 87 & 87 \\
\hline Number of Instruments, $i$ & 71 & 73 & 72 & 76 & 80 & 82 & 81 & 85 \\
\hline Instrument ratio, $r=n / i$ & 1.21 & 1.18 & 1.19 & 1.13 & 1.09 & 1.06 & 1.07 & 1.02 \\
\hline Limit the no.of lags of dependent & & & & & & & & \\
\hline variable used in instrumentation? & No & No & No & No & No & No & No & No \\
\hline
\end{tabular}

FDI risk reflects the risk of exprorpriation and government contraints on profit repatriation; corruption reflects the level of corruption within the political system; law and order measures the effectiveness of the rule of law; bureaucracy refers to the institutional strength and quality of the bureaucracy; conflict is the average of internal conflict and external conflict; and instability of government reflects the ability of government to stay in office.

The data are normalized to lie between zero and one, such that a higher number implies more corruption, better law enforcement, higher FDI risk and more political instability. 
Table 8: Robustness Regressions. Endogenous Democracy and Natural Resources

\begin{tabular}{|c|c|c|c|c|c|c|c|c|}
\hline \multirow[b]{2}{*}{ Variables } & \multicolumn{4}{|c|}{ Difference GMM } & \multicolumn{4}{|c|}{ System GMM } \\
\hline & $\begin{array}{l}\quad(1) \\
\text { dem is } \\
\text { endogenous }\end{array}$ & $\begin{array}{c}\text { (2) } \\
\text { dem \& nat } \\
\text { endogenous }\end{array}$ & $\begin{array}{l}\text { (3) } \\
\text { dem is } \\
\text { endogenous }\end{array}$ & $\begin{array}{l}\text { (4) } \\
\text { dem \& nat } \\
\text { endogenous }\end{array}$ & $\begin{array}{l}\quad(5) \\
\text { dem is } \\
\text { endogenous }\end{array}$ & $\begin{array}{l}\text { (6) } \\
\text { dem \& nat } \\
\text { endogenous }\end{array}$ & $\begin{array}{l}\quad(7) \\
\text { dem is } \\
\text { endogenous }\end{array}$ & $\begin{array}{c}\text { (8) } \\
\text { dem \& nat } \\
\text { endogenous }\end{array}$ \\
\hline dem, $\widehat{\alpha}$ & $\begin{array}{l}3.982^{* * * *} \\
(0.000)\end{array}$ & $\begin{array}{l}2.474^{* * *} \\
(0.000)\end{array}$ & $\begin{array}{l}3.775^{* * *} \\
(0.000)\end{array}$ & $\begin{array}{l}3.563^{* * *} \\
(0.000)\end{array}$ & $\begin{array}{l}1.769^{* * * *} \\
(0.000)\end{array}$ & $\begin{array}{l}1.601^{* * *} \\
(0.000)\end{array}$ & $\begin{array}{l}1.338^{* * * *} \\
(0.000)\end{array}$ & $\begin{array}{l}1.558^{* * *} \\
(0.000)\end{array}$ \\
\hline nat $\times \operatorname{dem}, \widehat{\beta}$ & $\begin{array}{l}-0.092^{* * *} \\
(0.000)\end{array}$ & $\begin{array}{l}-0.062^{* * *} \\
(0.000)\end{array}$ & $\begin{array}{l}-0.107^{* * *} \\
(0.000)\end{array}$ & $\begin{array}{l}-0.107^{* * *} \\
(0.000)\end{array}$ & $\begin{array}{l}-0.036^{* * *} \\
(0.000)\end{array}$ & $\begin{array}{l}-0.048^{* * *} \\
(0.000)\end{array}$ & $\begin{array}{l}-0.027^{* * *} \\
(0.000)\end{array}$ & $\begin{array}{l}-0.046^{* * *} \\
(0.000)\end{array}$ \\
\hline Number of Observations & 566 & 566 & 566 & 566 & 652 & 652 & 652 & 652 \\
\hline Number of Countries, $n$ & 106 & 106 & 106 & 106 & 112 & 112 & 112 & 112 \\
\hline Number of Instruments, $i$ & 197 & 259 & 89 & 97 & 224 & 295 & 110 & 105 \\
\hline Instrument ratio, $r=n / i$ & 0.57 & 0.41 & 1.19 & 1.09 & 0.50 & 0.38 & 1.02 & 1.07 \\
\hline $\begin{array}{l}\text { Limit the no.of lags of dependent } \\
\text { variable used in instrumentation? } \\
\text { Limit the no.of lags of endogenous }\end{array}$ & No & No & Yes, 2 & Yes, 2 & No & No & Yes, 8 & Yes, 4 \\
\hline variables used in instrumentation? & No & No & No & No & No & No & Yes, 2 & Yes, 2 \\
\hline
\end{tabular}


Appendix

Table A1: Countries included in Regressions

\begin{tabular}{|c|c|c|c|c|c|c|c|c|c|c|c|}
\hline \multicolumn{5}{|c|}{ In Sub-Saharan Africa } & \multirow{2}{*}{$\begin{array}{l}\text { Natural } \\
\text { Resource }\end{array}$} & \multicolumn{5}{|c|}{ Outside Sub-Saharan Africa } & \multirow{2}{*}{$\begin{array}{l}\text { Natural } \\
\text { Resource }\end{array}$} \\
\hline Country & Code & Free & Polity & Icrg & & Country & Code & Free & Polity & Icrg & \\
\hline Angola $^{a}$ & $\mathrm{AGO}$ & 0.06 & NA & 0.37 & 99.69 & Albania $^{c}$ & ALB & 0.60 & 0.77 & 0.68 & 11.09 \\
\hline Benin & BEN & 0.81 & 0.80 & NA & 4.75 & Algeria & DZA & 0.18 & 0.26 & 0.46 & 97.00 \\
\hline Botswana $^{a}$ & BWA & 0.83 & 0.95 & 0.56 & 8.30 & Argentina & ARG & 0.81 & 0.88 & 0.77 & 16.04 \\
\hline Burkina Faso & BFA & 0.33 & 0.33 & 0.54 & 1.15 & Armenia $^{c}$ & $\mathrm{ARM}$ & 0.44 & 0.69 & 0.59 & 26.12 \\
\hline Burundi & BDI & 0.31 & 0.48 & NA & 1.74 & Azerbaijan $^{c}$ & AZE & 0.17 & 0.17 & 0.31 & 79.35 \\
\hline Cameroon $^{a}$ & CMR & 0.12 & 0.22 & 0.41 & 43.28 & Bangladesh $^{b}$ & BGD & 0.63 & 0.64 & 0.56 & 0.82 \\
\hline Central Afr. Rep. & CAF & 0.42 & 0.54 & NA & 22.07 & Barbados & $\mathrm{BRB}$ & 1.00 & NA & NA & 6.80 \\
\hline Congo, Rep. ${ }^{a}$ & $\mathrm{COG}$ & 0.30 & 0.53 & 0.58 & 90.65 & Belarus $^{c}$ & BLR & 0.08 & 0.15 & 0.27 & 24.17 \\
\hline Cote d'Ivoire & CIV & 0.15 & 0.24 & 0.41 & 17.2 & Belize & BLZ & 1.00 & NA & NA & 15.81 \\
\hline Ethiopia & ETH & 0.34 & 0.55 & 0.57 & 2.18 & Bhutan $^{b}$ & BTN & 0.00 & 0.00 & NA & 32.54 \\
\hline Gabon $^{a}$ & GAB & 0.28 & 0.26 & 0.51 & 84.72 & Bolivia & $\mathrm{BOL}$ & 0.82 & 0.93 & 0.63 & 63.77 \\
\hline Gambia & GMB & 0.21 & 0.23 & 0.60 & 1.66 & Brazil & BRA & 0.78 & 0.83 & 0.65 & 13.95 \\
\hline Ghana & GHA & 0.64 & 0.60 & 0.48 & 16.65 & Bulgaria $^{c}$ & BGR & 0.93 & 0.93 & 0.85 & 21.33 \\
\hline Kenya & KEN & 0.28 & 0.35 & 0.56 & 15.36 & Cambodia $^{b}$ & CAM & 0.17 & 0.60 & NA & 0.01 \\
\hline Lesotho $^{a}$ & LSO & 0.72 & 0.90 & NA & 0.05 & Chile & CHL & 0.72 & 0.75 & 0.62 & 52.84 \\
\hline Madagascar & MDG & 0.59 & 0.66 & 0.72 & 8.44 & China & $\mathrm{CHN}$ & 0.02 & 0.15 & 0.35 & 7.50 \\
\hline Malawi & MWI & 0.42 & 0.42 & 0.45 & 0.20 & Colombia & $\mathrm{COL}$ & 0.67 & 0.88 & 0.63 & 31.03 \\
\hline Mali & MLI & 0.8 & 0.80 & 0.56 & 1.31 & Costa Rica & CRI & 1.00 & 1.00 & 0.85 & 1.71 \\
\hline Mauritania $^{a}$ & MRT & 0.17 & 0.20 & NA & 43.2 & Croatia $^{c}$ & HRV & 0.72 & 0.66 & 0.78 & 13.69 \\
\hline Mauritius & MUS & 0.98 & 1.00 & NA & 0.74 & Czech Republic $^{c}$ & CZE & 1.00 & 1.00 & 0.87 & 5.57 \\
\hline Mozambique & MOZ & 0.67 & 0.8 & 0.56 & 44.56 & Dominica & DMA & 0.92 & NA & NA & 0.95 \\
\hline Niger & NER & 0.42 & 0.65 & 0.59 & 59.54 & Dominican Rep. & DOM & 0.83 & 0.83 & 0.65 & 2.81 \\
\hline Nigeria & NGA & 0.28 & 0.43 & 0.43 & 96.48 & Ecuador & $\mathrm{ECU}$ & 0.77 & 0.89 & 0.67 & 47.73 \\
\hline Rwanda & RWA & 0.06 & 0.26 & NA & 22.09 & Egypt & EGY & 0.24 & 0.22 & 0.53 & 51.06 \\
\hline Senegal & SEN & 0.65 & 0.62 & 0.62 & 22.87 & El Salvador & SLV & 0.75 & 0.83 & 0.54 & 5.35 \\
\hline Seychelles $^{a}$ & SYC & 0.33 & $\mathrm{NA}$ & NA & 54.02 & Estonia $^{c}$ & EST & 0.99 & 0.8 & 0.84 & 10.45 \\
\hline Sierra Leone & SLE & 0.39 & 0.15 & $\mathrm{NA}$ & 35.99 & Fiji & FJI & 0.48 & 0.75 & NA & 0.30 \\
\hline South Africa & $\mathrm{ZAF}$ & 0.80 & 0.88 & 0.73 & 19.94 & Georgia & GEO & 0.58 & 0.76 & NA & 28.27 \\
\hline Sudan & SDN & 0.04 & 0.17 & 0.32 & 31.90 & Grenada & GRD & 0.96 & NA & NA & 0.10 \\
\hline Swaziland & SWZ & 0.06 & 0.05 & NA & 1.06 & Guatemala & GTM & 0.58 & 0.72 & 0.56 & 4.82 \\
\hline Tanzania & TZA & 0.49 & 0.53 & 0.65 & 9.67 & Guyana & GUY & 0.81 & 0.80 & 0.82 & 14.50 \\
\hline Togo & TGO & 0.17 & 0.30 & 0.27 & 36.90 & Haiti & HTI & 0.24 & 0.47 & 0.24 & 0.09 \\
\hline Uganda & UGA & 0.33 & 0.34 & 0.37 & 4.31 & Honduras & HND & 0.73 & 0.81 & 0.52 & 5.49 \\
\hline Zambia & ZMB & 0.53 & 0.71 & 0.67 & 79.12 & Hungary & HUN & 0.95 & 0.96 & 0.89 & 5.37 \\
\hline Zimbabwe & ZWE & 0.26 & 0.31 & 0.43 & 16.53 & India $^{b}$ & IND & 0.78 & 0.92 & 0.75 & 9.71 \\
\hline
\end{tabular}

The democracy data are normalized so they range from zero to one. A higher number implies more democracy.

Natural resources is the share of fuel and minerals in total merchandize exports (\%). All the data are averaged from 1982-2007.

${ }^{a}$ refers to countries in Sub-Saharan Africa that are not low-income. 
Table A1 continued. Countries Outside Sub-Saharan Africa

\begin{tabular}{|c|c|c|c|c|c|c|c|c|c|c|c|}
\hline & & & & & Natural & & & & & & Natural \\
\hline Country & Code & Free & Polity & Icrg & Resource & Country & Code & Free & Polity & Icrg & Resource \\
\hline Indonesia & IDN & 0.41 & 0.41 & 0.57 & 42.45 & Papua Guinea $^{b}$ & PNG & 0.83 & 1.00 & 0.81 & 55.09 \\
\hline Iran & IRN & 0.17 & 0.46 & 0.61 & 83.37 & Paraguay & PAY & 0.58 & 0.85 & 0.45 & 0.67 \\
\hline Jamaica & JAM & 0.83 & 0.97 & 0.71 & 12.61 & Peru & PER & 0.67 & 0.79 & 0.55 & 54.85 \\
\hline Jordan & JOR & 0.38 & 0.29 & 0.58 & 27.24 & Philippines & PHL & 0.70 & 0.78 & 0.74 & 7.08 \\
\hline Kazakhstan & $\mathrm{KAZ}$ & 0.17 & 0.26 & 0.26 & 70.10 & Poland ${ }^{c}$ & POL & 0.94 & 0.90 & 0.82 & 13.45 \\
\hline Kyrgyz & KGZ & 0.31 & 0.38 & NA & 22.65 & Romania $^{c}$ & ROM & 0.75 & 0.87 & 0.86 & 12.74 \\
\hline Iran & IRN & 0.17 & 0.46 & 0.61 & 83.37 & Russian & RUS & 0.40 & 0.78 & 0.56 & 56.68 \\
\hline Jamaica & JAM & 0.83 & 0.97 & 0.71 & 12.61 & Slovak Rep ${ }^{c}$ & SVK & 0.96 & 0.93 & 0.89 & 8.84 \\
\hline Jordan & JOR & 0.38 & 0.29 & 0.58 & 27.24 & Sri Lanka & LKA & 0.61 & 0.75 & 0.71 & 3.47 \\
\hline Kazakhstan $^{c}$ & $\mathrm{KAZ}$ & 0.17 & 0.26 & 0.26 & 70.10 & St. Kitts & KAN & 0.99 & NA & NA & 0.03 \\
\hline Kyrgyz $^{c}$ & KGZ & 0.31 & 0.38 & NA & 22.65 & St. Lucia & LCA & 1.00 & $\mathrm{NA}$ & NA & 0.03 \\
\hline Latvia & LAV & 0.94 & 0.90 & 0.83 & 6.54 & St. Vincent & VCT & 0.83 & NA & NA & 0.07 \\
\hline Lithuania $^{c}$ & LTU & 0.99 & 1.00 & 0.88 & 21.85 & Syrian & SYR & 0.04 & 0.08 & 0.25 & 62.42 \\
\hline Malaysia & MYS & 0.47 & 0.67 & 0.68 & 16.91 & Thailand & THA & 0.62 & 0.75 & 0.58 & 3.55 \\
\hline Mexico & MEX & 0.66 & 0.66 & 0.77 & 28.04 & Trinidad & TTO & 0.92 & 0.96 & 0.52 & 63.30 \\
\hline Moldova & MDA & 0.70 & 0.88 & 0.80 & 2.91 & Tunisia & TUN & 0.21 & 0.26 & 0.42 & 19.83 \\
\hline Mongolia $^{b}$ & $\mathrm{MNG}$ & 0.83 & 0.99 & 0.68 & 52.09 & Turkey & TUR & 0.62 & 0.85 & 0.73 & 5.23 \\
\hline Morocco & MAR & 0.38 & 0.15 & 0.49 & 17.51 & Ukraine $^{c}$ & UKR & 0.61 & 0.83 & 0.65 & 14.38 \\
\hline Nepal & NPL & 0.57 & 0.53 & NA & 1.31 & Uruguay & URY & 0.91 & 0.90 & 0.72 & 1.68 \\
\hline Nicaragua & NIC & 0.67 & 0.91 & 1.00 & 2.55 & Vanuatu & VUT & 0.94 & NA & NA & 0.06 \\
\hline Oman & OMN & 0.17 & 0.08 & 0.17 & 84.84 & Venezuela & VEN & 0.76 & 0.88 & 0.76 & 88.39 \\
\hline Pakistan $^{b}$ & PAK & 0.35 & 0.52 & 0.31 & 2.26 & Vietnam $^{b}$ & VNM & 0.00 & 0.15 & 0.14 & 22.15 \\
\hline Panama & PAN & 0.70 & 0.74 & 0.65 & 5.54 & Yemen $^{b}$ & YEM & 0.31 & 0.40 & 0.65 & 78.86 \\
\hline
\end{tabular}

${ }^{b}$ refers to countries outside Sub-Saharan Africa that are low-income and ${ }^{c}$ refers to transition countries. 
Studies on the Effect of Democracy on FDI

\begin{tabular}{|c|c|c|c|c|c|c|}
\hline Author & $\begin{array}{l}\text { Year } \\
\text { Published }\end{array}$ & $\begin{array}{l}\text { No of } \\
\text { Countries }\end{array}$ & $\begin{array}{l}\text { Period } \\
\text { of Study }\end{array}$ & $\begin{array}{l}\text { Measure of } \\
\text { Democracy }\end{array}$ & $\begin{array}{l}\text { Estimation } \\
\text { Procedure }\end{array}$ & $\begin{array}{l}\text { Estimated } \\
\text { Effect }\end{array}$ \\
\hline Oneal & 1994 & 48 & $1950-1985$ & Polity & OLS & Insignificant \\
\hline Rodrik & 1996 & 40 & 1982-1989 & Freedom House & OLS & Positive \\
\hline Alesina \& Dollar & 2000 & 124 & 1970-1994 & $\begin{array}{l}\text { Freedom House } \\
\text { Polity }\end{array}$ & OLS & Insignificant \\
\hline Harms \& Ursprung & 2002 & 124 & 1989-1997 & Freedom House & $\begin{array}{l}\text { OLS } \\
\text { Fixed Effects }\end{array}$ & Positive \\
\hline Li \& Resnick & 2003 & 62 & $1982-1995$ & Polity & $\begin{array}{l}\text { OLS } \\
\text { Fixed Effects }\end{array}$ & Negative \\
\hline Jensen & 2003 & 114 & $1970-1997$ & Polity & $\begin{array}{l}\text { OLS } \\
\text { Fixed Effects }\end{array}$ & Positive \\
\hline Busse & 2004 & 69 & $1972-2001$ & Freedom House & OLS & $\begin{array}{l}\text { Positive for } \\
\text { 1990-2001; } \\
\text { Insignificant } \\
\text { for 1972-1990 }\end{array}$ \\
\hline Jakobsen & 2006 & 96 & 1983-2001 & $\begin{array}{l}\text { Freedom House } \\
\text { Polity }\end{array}$ & OLS & Positive \\
\hline Jakobsen \& de Soysa & 2006 & 99 & 1984-2001 & Polity & OLS & Positive \\
\hline Adam \& Fillippaios & 2007 & 105 & 1989-1997 & Freedom House & Fixed Effects & Positive \\
\hline Busse \& Hefeker & 2007 & 83 & $1983-2003$ & $\begin{array}{l}\text { International } \\
\text { Country Risk } \\
\text { Guide (ICRG) }\end{array}$ & $\begin{array}{l}\text { Fixed Effects } \\
\text { Dynamic Panel } \\
\text { (Arrelano-Bond) }\end{array}$ & Positive \\
\hline Buthe \& Milner & 2008 & 129 & $1970-2000$ & Freedom House & Fixed Effects & Insignificant \\
\hline
\end{tabular}


Table 1: The Interaction Effect of Democracy and Natural Resources on FDI

\begin{tabular}{|c|c|c|c|c|c|c|}
\hline \multirow[b]{3}{*}{ Variables } & \multicolumn{3}{|c|}{ Difference GMM } & \multicolumn{3}{|c|}{ System GMM } \\
\hline & $(1)$ & $(2)$ & $(3)$ & $(4)$ & $(5)$ & $(6)$ \\
\hline & Free & Polity & Icrg & Free & Polity & Icrg \\
\hline Democracy, dem, $\widehat{\alpha}$ & $\begin{array}{c}2.528^{* * *} \\
(0.000)\end{array}$ & $\begin{array}{c}2.048^{* * *} \\
(0.000)\end{array}$ & $\begin{array}{c}6.274^{* * *} \\
(0.000)\end{array}$ & $\begin{array}{c}2.205^{* * *} \\
(0.000)\end{array}$ & $\begin{array}{c}2.120 * * * \\
(0.000)\end{array}$ & $\begin{array}{c}5.813^{* * *} \\
(0.000)\end{array}$ \\
\hline Natural Resources, nat & $\begin{array}{c}-0.016^{* * *} \\
(0.006)\end{array}$ & $\begin{array}{c}-0.018^{* * *} \\
(0.005)\end{array}$ & $\begin{array}{c}0.011 \\
(0.111)\end{array}$ & $\begin{array}{c}-0.014^{* * *} \\
(0.000)\end{array}$ & $\begin{array}{c}-0.014^{* * *} \\
(0.000)\end{array}$ & $\begin{array}{c}0.026^{* * *} \\
(0.000)\end{array}$ \\
\hline nat $\times \operatorname{dem}, \widehat{\beta}$ & $\begin{array}{c}-0.039^{* * *} \\
(0.000)\end{array}$ & $\begin{array}{c}-0.041^{* * *} \\
(0.000)\end{array}$ & $\begin{array}{c}-0.112^{* * *} \\
(0.000)\end{array}$ & $\begin{array}{c}-0.043^{* * *} \\
(0.000)\end{array}$ & $\begin{array}{c}-0.041^{* * *} \\
(0.000)\end{array}$ & $\begin{array}{c}-0.113^{* * *} \\
(0.000)\end{array}$ \\
\hline Other variables & & & & & & \\
\hline Lagged FDI/GDP & $\begin{array}{c}-0.251^{* * *} \\
(0.000)\end{array}$ & $\begin{array}{c}-0.184^{* * *} \\
(0.000)\end{array}$ & $\begin{array}{c}-0.218^{* * *} \\
(0.000)\end{array}$ & $\begin{array}{c}-0.082^{* * *} \\
(0.000)\end{array}$ & $\begin{array}{c}-0.018^{* * *} \\
(0.000)\end{array}$ & $\begin{array}{c}-0.117^{* * *} \\
(0.000)\end{array}$ \\
\hline Trade/GDP & $\begin{array}{c}0.021^{* * *} \\
(0.000)\end{array}$ & $\begin{array}{c}0.018^{* * *} \\
(0.000)\end{array}$ & $\begin{array}{c}0.018^{* * *} \\
(0.000)\end{array}$ & $\begin{array}{c}0.017^{* * *} \\
(0.000)\end{array}$ & $\begin{array}{c}0.007^{* * *} \\
(0.000)\end{array}$ & $\begin{array}{c}-0.005^{* * *} \\
(0.000)\end{array}$ \\
\hline Fixed Investment/GDP & $\begin{array}{c}0.236^{* * *} \\
(0.000)\end{array}$ & $\begin{array}{c}0.226^{* * *} \\
(0.000)\end{array}$ & $\begin{array}{c}0.219^{* * *} \\
(0.000)\end{array}$ & $\begin{array}{c}0.249 * * * \\
(0.000)\end{array}$ & $\begin{array}{c}0.252^{* * *} \\
(0.000)\end{array}$ & $\begin{array}{c}0.227^{* * *} \\
(0.000)\end{array}$ \\
\hline Ln (1 + Phones $)$ & $\begin{array}{c}2.151^{* * *} \\
(0.000)\end{array}$ & $\begin{array}{c}1.760^{* * *} \\
(0.000)\end{array}$ & $\begin{array}{c}1.927^{* * *} \\
(0.000)\end{array}$ & $\begin{array}{c}2.523^{* * *} \\
(0.000)\end{array}$ & $\begin{array}{c}2.132^{* * *} \\
(0.000)\end{array}$ & $\begin{array}{c}2.417^{* * *} \\
(0.000)\end{array}$ \\
\hline Inflation & $\begin{array}{c}-0.004^{* * *} \\
(0.000)\end{array}$ & $\begin{array}{c}-0.004^{* * *} \\
(0.000)\end{array}$ & $\begin{array}{c}-0.002^{* * *} \\
(0.000)\end{array}$ & $\begin{array}{c}-0.003^{* * *} \\
(0.000)\end{array}$ & $\begin{array}{c}-0.002^{* * *} \\
(0.000)\end{array}$ & $\begin{array}{l}-0.000 \\
(0.171)\end{array}$ \\
\hline $\operatorname{lgdpc}=\operatorname{Ln}($ GDP per capita $)$ & $\begin{array}{l}-4.276 \\
(0.104)\end{array}$ & $\begin{array}{c}-7.847^{* * *} \\
(0.000)\end{array}$ & $\begin{array}{c}-11.044^{* * *} \\
(0.000)\end{array}$ & $\begin{array}{l}-0.154 \\
(0.915)\end{array}$ & $\begin{array}{c}-3.812^{* * *} \\
(0.000)\end{array}$ & $\begin{array}{c}-2.864^{* *} \\
(0.014)\end{array}$ \\
\hline $\operatorname{lgdpc} \times \operatorname{lgdpc}$ & $\begin{array}{c}0.195 \\
(0.256)\end{array}$ & $\begin{array}{c}0.466^{* * *} \\
(0.000)\end{array}$ & $\begin{array}{c}0.605^{* * *} \\
(0.000)\end{array}$ & $\begin{array}{l}-0.107 \\
(0.270)\end{array}$ & $\begin{array}{c}0.209^{* * *} \\
(0.009)\end{array}$ & $\begin{array}{c}0.185^{* *} \\
(0.020)\end{array}$ \\
\hline Constant & $\begin{array}{c}12.507 \\
(0.209)\end{array}$ & $\begin{array}{c}24.950^{* * *} \\
(0.000)\end{array}$ & $\begin{array}{c}38.663^{* * *} \\
(0.000)\end{array}$ & $\begin{array}{l}-1.846 \\
(0.727)\end{array}$ & $\begin{array}{c}9.007 * * \\
(0.043)\end{array}$ & $\begin{array}{c}2.614 \\
(0.546)\end{array}$ \\
\hline Hansen J Test (p-value) & 0.320 & 0.511 & 0.239 & 0.414 & 0.350 & 0.650 \\
\hline Serial Correlation Test (p-value) & 0.645 & 0.518 & 0.900 & 0.481 & 0.468 & 0.650 \\
\hline Number of Observations & 566 & 541 & 455 & 652 & 614 & 551 \\
\hline Number of Countries, $n$ & 106 & 98 & 86 & 112 & 102 & 87 \\
\hline Number of Instruments, $i$ & 73 & 73 & 70 & 82 & 82 & 79 \\
\hline Instrument ratio, $r=n / i$ & 1.45 & 1.34 & 1.23 & 1.37 & 1.17 & 1.10 \\
\hline $\begin{array}{l}\text { Limit the no of lags of dependent } \\
\text { variable used in instrumentation? }\end{array}$ & No & No & No & No & No & No \\
\hline
\end{tabular}


Table 2: The Interaction Effect of Fuel, Minerals and Democracy on FDI Difference GMM

\begin{tabular}{|c|c|c|c|c|c|c|}
\hline \multirow[b]{3}{*}{ Variables } & \multicolumn{3}{|c|}{ Difference GMM } & \multicolumn{3}{|c|}{ System GMM } \\
\hline & $(1)$ & $(2)$ & $(3)$ & $(4)$ & $(5)$ & $(6)$ \\
\hline & Free & Polity & $\operatorname{Icrg}$ & Free & Polity & $\operatorname{Icrg}$ \\
\hline Democracy, dem, $\widehat{\alpha}$ & $\begin{array}{l}2.657^{* * *} \\
(0.000)\end{array}$ & $\begin{array}{l}1.971^{* * *} \\
(0.000)\end{array}$ & $\begin{array}{l}6.008^{* * *} \\
(0.000)\end{array}$ & $\begin{array}{l}2.060 * * * \\
(0.000)\end{array}$ & $\begin{array}{l}2.115^{* * *} \\
(0.000)\end{array}$ & $\begin{array}{l}5.685^{* * *} \\
(0.000)\end{array}$ \\
\hline Fuel and Oil, $f e$ & $\begin{array}{l}-0.026^{* * *} \\
(0.001)\end{array}$ & $\begin{array}{l}-0.038^{* * *} \\
(0.000)\end{array}$ & $\begin{array}{l}0.003 \\
(0.720)\end{array}$ & $\begin{array}{l}-0.020^{* * *} \\
(0.000)\end{array}$ & $\begin{array}{l}-0.023^{* * *} \\
(0.000)\end{array}$ & $\begin{array}{l}0.014^{* *} \\
(0.010)\end{array}$ \\
\hline Minerals, me & $\begin{array}{l}0.023^{* * *} \\
(0.005)\end{array}$ & $\begin{array}{l}0.018^{* * * *} \\
(0.001)\end{array}$ & $\begin{array}{l}0.070^{* * *} \\
(0.000)\end{array}$ & $\begin{array}{l}0.008 \\
(0.253)\end{array}$ & $\begin{array}{l}0.023^{* * *} \\
(0.000)\end{array}$ & $\begin{array}{l}0.063^{* * *} \\
(0.000)\end{array}$ \\
\hline$f e \times \operatorname{dem}, \widehat{\beta_{1}}$ & $\begin{array}{l}-0.043^{* * *} \\
(0.000)\end{array}$ & $\begin{array}{l}-0.034^{* * *} \\
(0.000)\end{array}$ & $\begin{array}{l}-0.116^{* * *} \\
(0.000)\end{array}$ & $\begin{array}{l}-0.045^{* * *} \\
(0.000)\end{array}$ & $\begin{array}{l}-0.046^{* * *} \\
(0.000)\end{array}$ & $\begin{array}{l}-0.101^{* * *} \\
(0.000)\end{array}$ \\
\hline$m e \times d e m, \widehat{\beta_{2}}$ & $\begin{array}{l}-0.034^{* * *} \\
(0.002)\end{array}$ & $\begin{array}{l}-0.041^{* * *} \\
(0.000)\end{array}$ & $\begin{array}{l}-0.120^{* * *} \\
(0.000)\end{array}$ & $\begin{array}{l}-0.035^{* * *} \\
(0.000)\end{array}$ & $\begin{array}{l}-0.037^{* * *} \\
(0.000)\end{array}$ & $\begin{array}{l}-0.131^{* * *} \\
(0.000)\end{array}$ \\
\hline$H_{o}: \beta_{1}=\beta_{2}$ (P-values $)$ & 0.556 & 0.470 & 0.701 & 0.390 & 0.252 & 0.000 \\
\hline Reject $\mathrm{H}_{0}$ ? & No & No & No & No & No & Yes \\
\hline \multicolumn{7}{|l|}{ Other variables } \\
\hline Lagged FDI/GDP & $\begin{array}{l}-0.237^{* * *} \\
(0.000)\end{array}$ & $\begin{array}{l}-0.175^{* * *} \\
(0.000)\end{array}$ & $\begin{array}{l}-0.208^{* * *} \\
(0.000)\end{array}$ & $\begin{array}{l}-0.072^{* * *} \\
(0.000)\end{array}$ & $\begin{array}{l}-0.006 \\
(0.319)\end{array}$ & $\begin{array}{l}-0.106^{* * *} \\
(0.000)\end{array}$ \\
\hline Trade/GDP & $\begin{array}{l}0.021^{* * *} \\
(0.000)\end{array}$ & $\begin{array}{l}0.018^{* * *} \\
(0.000)\end{array}$ & $\begin{array}{l}0.017 * * * \\
(0.000)\end{array}$ & $\begin{array}{l}0.018^{* * *} \\
(0.000)\end{array}$ & $\begin{array}{l}0.008^{* * *} \\
(0.000)\end{array}$ & $\begin{array}{l}-0.004^{* * *} \\
(0.001)\end{array}$ \\
\hline Fixed Investment/GDP & $\begin{array}{l}0.237^{* * *} \\
(0.000)\end{array}$ & $\begin{array}{l}0.229^{* * *} \\
(0.000)\end{array}$ & $\begin{array}{l}0.221^{* * *} \\
(0.000)\end{array}$ & $\begin{array}{l}0.247^{* * *} \\
(0.000)\end{array}$ & $\begin{array}{l}0.257^{* * *} \\
(0.000)\end{array}$ & $\begin{array}{l}0.226^{* * *} \\
(0.000)\end{array}$ \\
\hline Ln $(1+$ Phones $)$ & $\begin{array}{l}2.213^{* * *} \\
(0.000)\end{array}$ & $\begin{array}{l}1.845^{* * *} \\
(0.000)\end{array}$ & $\begin{array}{l}2.137^{* * *} \\
(0.000)\end{array}$ & $\begin{array}{l}2.601^{* * *} \\
(0.000)\end{array}$ & $\begin{array}{l}2.210^{* * *} \\
(0.000)\end{array}$ & $\begin{array}{l}2.468^{* * *} \\
(0.000)\end{array}$ \\
\hline Inflation & $\begin{array}{l}-0.004^{* * *} \\
(0.000)\end{array}$ & $\begin{array}{l}-0.004^{* * *} \\
(0.000)\end{array}$ & $\begin{array}{l}-0.002^{* * *} \\
(0.000)\end{array}$ & $\begin{array}{l}-0.003^{* * *} \\
(0.000)\end{array}$ & $\begin{array}{l}-0.003^{* * *} \\
(0.000)\end{array}$ & $\begin{array}{l}-0.001^{* *} \\
(0.036)\end{array}$ \\
\hline $\operatorname{lgdpc}=\operatorname{Ln}(\mathrm{GDP}$ per capita $)$ & $\begin{array}{l}-6.880^{* * *} \\
(0.005)\end{array}$ & $\begin{array}{l}-8.965^{* * *} \\
(0.000)\end{array}$ & $\begin{array}{l}-13.550^{* * *} \\
(0)\end{array}$ & $\begin{array}{l}-0.420 \\
(0.761)\end{array}$ & $\begin{array}{l}-4.346^{* * *} \\
(0.000)\end{array}$ & $\begin{array}{l}-3.406^{* * *} \\
(0.001)\end{array}$ \\
\hline $\operatorname{lgdpc} \times \lg d p c$ & $\begin{array}{l}0.345^{* *} \\
(0.042)\end{array}$ & $\begin{array}{l}0.516^{* * *} \\
(0.000)\end{array}$ & $\begin{array}{l}0.770^{* * * *} \\
(0.000)\end{array}$ & $\begin{array}{l}-0.103 \\
(0.275)\end{array}$ & $\begin{array}{l}0.236^{* * *} \\
(0.002)\end{array}$ & $\begin{array}{l}0.216^{* * *} \\
(0.003)\end{array}$ \\
\hline Constant & $\begin{array}{l}22.996^{* * *} \\
(0.010)\end{array}$ & $\begin{array}{l}30.123^{* * *} \\
(0.000)\end{array}$ & $\begin{array}{l}47.444^{* * *} \\
(0.000)\end{array}$ & $\begin{array}{l}-0.305 \\
(0.951)\end{array}$ & $\begin{array}{l}10.919^{* * *} \\
(0.006)\end{array}$ & $\begin{array}{l}4.561 \\
(0.238)\end{array}$ \\
\hline Hansen J Test (p-value) & 0.245 & 0.438 & 0.387 & 0.438 & 0.319 & 0.519 \\
\hline Serial Correlation Test (p-value) & 0.617 & 0.491 & 0.803 & 0.463 & 0.455 & 0.625 \\
\hline Number of Observations & 566 & 541 & 455 & 652 & 614 & 551 \\
\hline Number of Countries, $n$ & 106 & 98 & 86 & 112 & 102 & 87 \\
\hline Number of Instruments, $i$ & 75 & 75 & 72 & 84 & 84 & 81 \\
\hline Instrument ratio, $r=n / i$ & 1.41 & 1.31 & 1.19 & 1.33 & 1.21 & 1.07 \\
\hline $\begin{array}{l}\text { Limit the no.of lags of dependent } \\
\text { variable used in instrumentation? }\end{array}$ & No & No & No & No & No & No \\
\hline
\end{tabular}


Table 3: Robustness Regressions. Subsamples: Difference GMM

\begin{tabular}{|c|c|c|c|c|c|c|c|c|}
\hline \multirow{2}{*}{ Variables } & \multirow{2}{*}{$\begin{array}{c}\text { Outside } \\
\text { Transition } \\
(1)\end{array}$} & \multirow{2}{*}{$\begin{array}{c}\text { Outside } \\
\text { SSA } \\
(2)\end{array}$} & \multicolumn{2}{|c|}{ Middle Income } & \multicolumn{2}{|c|}{ Low Income } & \multicolumn{2}{|c|}{ SSA } \\
\hline & & & $(3)$ & $(4)$ & $(5)$ & $(6)$ & $(7)$ & $(8)$ \\
\hline $\operatorname{dem}, \widehat{\alpha}$ & $\begin{array}{l}2.697^{* * *} \\
(0.000)\end{array}$ & $\begin{array}{l}3.052^{* * *} \\
(0.000)\end{array}$ & $\begin{array}{l}3.648^{* * *} \\
(0.000)\end{array}$ & $\begin{array}{l}2.620^{* * *} \\
(0.000)\end{array}$ & $\begin{array}{l}1.035^{* * *} \\
(0.000)\end{array}$ & $\begin{array}{l}0.966^{* * *} \\
(0.003)\end{array}$ & $\begin{array}{l}-0.471 \\
(0.782)\end{array}$ & $\begin{array}{l}0.799 * * \\
(0.013)\end{array}$ \\
\hline Natural Resources, nat & $\begin{array}{l}-0.023^{* * *} \\
(0.000)\end{array}$ & $\begin{array}{l}-0.061^{* * *} \\
(0.000)\end{array}$ & $\begin{array}{l}0.009^{* * *} \\
(0.001)\end{array}$ & $\begin{array}{l}-0.012 \\
(0.167)\end{array}$ & $\begin{array}{l}-0.035^{* * *} \\
(0.000)\end{array}$ & $\begin{array}{l}-0.023^{* *} \\
(0.030)\end{array}$ & $\begin{array}{l}0.002 \\
(0.681)\end{array}$ & $\begin{array}{l}0.000 \\
(0.942)\end{array}$ \\
\hline nat $\times \operatorname{dem}, \widehat{\beta}$ & $\begin{array}{l}-0.054^{* * *} \\
(0.000)\end{array}$ & $\begin{array}{l}-0.019^{* * *} \\
(0.000)\end{array}$ & $\begin{array}{l}-0.063^{* * *} \\
(0.000)\end{array}$ & $\begin{array}{l}-0.026^{* * *} \\
(0.003)\end{array}$ & $\begin{array}{l}-0.053^{* * *} \\
(0.000)\end{array}$ & $\begin{array}{l}-0.044^{* * *} \\
(0.000)\end{array}$ & $\begin{array}{l}-0.031 \\
(0.112)\end{array}$ & $\begin{array}{l}-0.056^{* * *} \\
(0.000)\end{array}$ \\
\hline Lagged FDI/GDP & $\begin{array}{l}0.083^{* * *} \\
(0.000)\end{array}$ & $\begin{array}{l}-0.291^{* * *} \\
(0.000)\end{array}$ & $\begin{array}{l}-0.305^{* * *} \\
(0.000)\end{array}$ & $\begin{array}{l}-0.287^{* * *} \\
(0.000)\end{array}$ & $\begin{array}{l}0.042^{* *} \\
(0.019)\end{array}$ & $\begin{array}{l}-0.017^{* *} \\
(0.044)\end{array}$ & $\begin{array}{l}0.403^{* * *} \\
(0.000)\end{array}$ & $\begin{array}{l}0.396^{* * *} \\
(0.000)\end{array}$ \\
\hline Trade/GDP & $\begin{array}{l}0.015^{* * *} \\
(0.000)\end{array}$ & $\begin{array}{l}0.021^{* * *} \\
(0.000)\end{array}$ & $\begin{array}{l}0.024^{* * *} \\
(0.000)\end{array}$ & $\begin{array}{l}0.031^{* * *} \\
(0.000)\end{array}$ & $\begin{array}{c}-0.013^{*} \\
(0.092)\end{array}$ & $\begin{array}{l}0.010^{* *} \\
(0.047)\end{array}$ & $\begin{array}{l}0.010 \\
(0.219)\end{array}$ & $\begin{array}{l}0.025^{* * *} \\
(0.000)\end{array}$ \\
\hline $\operatorname{lgdpc}=\operatorname{Ln}($ GDP per capita $)$ & $\begin{array}{c}-2.821^{*} \\
(0.058)\end{array}$ & $\begin{array}{l}-22.072^{* * *} \\
(0.000)\end{array}$ & $\begin{array}{l}-19.443^{* * *} \\
(0.000)\end{array}$ & $\begin{array}{l}-14.881^{* * *} \\
(0.002)\end{array}$ & $\begin{array}{l}32.744^{* * *} \\
(0.004)\end{array}$ & $\begin{array}{l}9.082 \\
(0.270)\end{array}$ & $\begin{array}{l}0.680 \\
(0.934)\end{array}$ & $\begin{array}{l}3.996 \\
(0.281)\end{array}$ \\
\hline $\lg d p c \times \lg d p c$ & $\begin{array}{l}0.226^{* *} \\
(0.030)\end{array}$ & $\begin{array}{l}1.327^{* * *} \\
(0.000)\end{array}$ & $\begin{array}{l}1.073^{* * *} \\
(0.000)\end{array}$ & $\begin{array}{l}0.794^{* * *} \\
(0.008)\end{array}$ & $\begin{array}{l}-2.528^{* * *} \\
(0.008)\end{array}$ & $\begin{array}{l}-0.624 \\
(0.376)\end{array}$ & $\begin{array}{l}-0.005 \\
(0.994)\end{array}$ & $\begin{array}{l}-0.282 \\
(0.358)\end{array}$ \\
\hline Inflation & $\begin{array}{l}-0.002^{\text {*** }} \\
(0.000)\end{array}$ & $\begin{array}{l}-0.004^{* * *} \\
(0.000)\end{array}$ & $\begin{array}{l}-0.004^{* * *} \\
(0.000)\end{array}$ & $\begin{array}{l}-0.004^{* * *} \\
(0.001)\end{array}$ & $\begin{array}{l}0.001 \\
(0.354)\end{array}$ & $\begin{array}{l}-0.002 \\
(0.155)\end{array}$ & $\begin{array}{l}-0.002^{* *} \\
(0.027)\end{array}$ & $\begin{array}{l}-0.003^{* *} \\
(0.020)\end{array}$ \\
\hline Fixed Investment/GDP & $\begin{array}{l}0.135^{* * *} \\
(0.000)\end{array}$ & $\begin{array}{l}0.299^{* * *} \\
(0.000)\end{array}$ & $\begin{array}{l}0.319^{* * *} \\
(0.000)\end{array}$ & $\begin{array}{l}0.330^{* * *} \\
(0.000)\end{array}$ & $\begin{array}{l}0.044^{* * *} \\
(0.006)\end{array}$ & $\begin{array}{l}0.017^{*} \\
(0.059)\end{array}$ & $\begin{array}{l}0.048^{* *} \\
(0.013)\end{array}$ & $\begin{array}{l}0.025^{* *} \\
(0.029)\end{array}$ \\
\hline Ln $(1+$ phones $)$ & $\begin{array}{l}1.043^{* * *} \\
(0.000)\end{array}$ & $\begin{array}{l}2.089^{* * *} \\
(0.000)\end{array}$ & $\begin{array}{l}2.650^{* * *} \\
(0.000)\end{array}$ & $\begin{array}{l}2.056^{* * *} \\
(0.000)\end{array}$ & $\begin{array}{l}1.586^{* * *} \\
(0.000)\end{array}$ & $\begin{array}{l}2.341^{* * *} \\
(0.001)\end{array}$ & $\begin{array}{l}-0.099 \\
(0.937)\end{array}$ & $\begin{array}{l}1.719^{* * *} \\
(0.000)\end{array}$ \\
\hline Constant & $\begin{array}{l}4.941 \\
(0.349)\end{array}$ & $\begin{array}{l}80.513^{* * *} \\
(0.000)\end{array}$ & $\begin{array}{l}72.586^{* * *} \\
(0.000)\end{array}$ & $\begin{array}{l}55.274^{* * *} \\
(0.004)\end{array}$ & $\begin{array}{l}-102.998^{* * *} \\
(0.002)\end{array}$ & $\begin{array}{l}-31.894 \\
(0.179)\end{array}$ & $\begin{array}{l}-3.701 \\
(0.883)\end{array}$ & $\begin{array}{l}-15.334 \\
(0.168)\end{array}$ \\
\hline Hansen J Test (p-value $)^{1}$ & 0.198 & 0.343 & 0.364 & 0.190 & 1.000 & 0.400 & 1.000 & 0.302 \\
\hline Serial Correlation Test (p-value $)^{2}$ & 0.105 & 0.753 & 0.768 & 0.777 & 0.750 & 0.657 & 0.192 & 0.146 \\
\hline Number of Observations & 504 & 427 & 409 & 409 & 157 & 157 & 139 & 139 \\
\hline Number of Countries, $n$ & 90 & 76 & 72 & 72 & 34 & 34 & 30 & 30 \\
\hline Number of Instruments, $i$ & 73 & 73 & 73 & 52 & 71 & 28 & 72 & 28 \\
\hline Instrument ratio, $r=n / i$ & 1.23 & 1.04 & 0.99 & 1.38 & 0.48 & 1.21 & 0.42 & 1.07 \\
\hline $\begin{array}{l}\text { Limit the no.of lags of dependent } \\
\text { variable used in instrumentation? }\end{array}$ & No & No & No & 5 & No & 2 & No & 2 \\
\hline
\end{tabular}


Table 4: Robustness Regressions. Subsamples: System GMM

\section{$\begin{array}{llll}\text { Outside } & \text { Outside SSA } & \text { Middle Income } & \text { Low Income }\end{array}$}

\section{Transition}

(8) (9)

\begin{tabular}{|c|c|c|c|c|c|c|c|c|c|}
\hline $\operatorname{dem}, \widehat{\alpha}$ & $\begin{array}{l}2.674^{* * *} \\
(0.000)\end{array}$ & $\begin{array}{l}2.070 * * * \\
(0.000)\end{array}$ & $\begin{array}{l}1.802^{* * *} \\
(0.000)\end{array}$ & $\begin{array}{l}3.315^{* * *} \\
(0.000)\end{array}$ & $\begin{array}{l}2.440^{* * *} \\
(0.000)\end{array}$ & $\begin{array}{l}2.763^{* * *} \\
(0.000)\end{array}$ & $\begin{array}{l}2.051^{* * *} \\
(0.000)\end{array}$ & $\begin{array}{l}2.744^{* * *} \\
(0.008)\end{array}$ & $\begin{array}{l}-0.082 \\
(0.831)\end{array}$ \\
\hline Natural Resources, nat & $\begin{array}{l}-0.014^{* * *} \\
(0.000)\end{array}$ & $\begin{array}{l}-0.036^{* * *} \\
(0.000)\end{array}$ & $\begin{array}{l}-0.041^{* * *} \\
(0.000)\end{array}$ & $\begin{array}{l}0.036^{* * *} \\
(0.000)\end{array}$ & $\begin{array}{l}0.028^{* * *} \\
(0.002)\end{array}$ & $\begin{array}{l}-0.040^{* * *} \\
(0.000)\end{array}$ & $\begin{array}{l}-0.044^{* * *} \\
(0.000)\end{array}$ & $\begin{array}{l}0.011^{* *} \\
(0.015)\end{array}$ & $\begin{array}{l}0.003 \\
(0.392)\end{array}$ \\
\hline nat $\times \operatorname{dem}, \widehat{\beta}$ & $\begin{array}{l}-0.075^{* * *} \\
(0.000)\end{array}$ & $\begin{array}{l}-0.007^{* * *} \\
(0.005)\end{array}$ & $\begin{array}{l}-0.012^{* * *} \\
(0.009)\end{array}$ & $\begin{array}{l}-0.063^{* * *} \\
(0.000)\end{array}$ & $\begin{array}{l}-0.032^{* * *} \\
(0.004)\end{array}$ & $\begin{array}{l}-0.030 * * * \\
(0.000)\end{array}$ & $\begin{array}{l}-0.010 \\
(0.109)\end{array}$ & $\begin{array}{l}-0.078^{* * *} \\
(0.000)\end{array}$ & $\begin{array}{l}-0.041^{* * *} \\
(0.000)\end{array}$ \\
\hline Lagged FDI/GDP & $\begin{array}{l}0.129 * * * \\
(0.000)\end{array}$ & $\begin{array}{l}-0.099^{* * *} \\
(0.000)\end{array}$ & $\begin{array}{l}-0.068^{* * *} \\
(0.000)\end{array}$ & $\begin{array}{l}-0.138^{* * *} \\
(0.000)\end{array}$ & $\begin{array}{l}-0.091^{* * *} \\
(0.000)\end{array}$ & $\begin{array}{l}0.219 * * * \\
(0.000)\end{array}$ & $\begin{array}{l}0.195^{* * *} \\
(0.000)\end{array}$ & $\begin{array}{l}0.594^{* * *} \\
(0.000)\end{array}$ & $\begin{array}{l}0.677 * * * \\
(0.000)\end{array}$ \\
\hline Trade/GDP & $\begin{array}{l}0.009^{* * *} \\
(0.000)\end{array}$ & $\begin{array}{l}0.022^{* * *} \\
(0.000)\end{array}$ & $\begin{array}{l}0.022^{* * *} \\
(0.000)\end{array}$ & $\begin{array}{l}0.028 * * * \\
(0.000)\end{array}$ & $\begin{array}{l}0.032^{* * *} \\
(0.000)\end{array}$ & $\begin{array}{l}0.004 \\
(0.636)\end{array}$ & $\begin{array}{l}0.022^{* * *} \\
(0.000)\end{array}$ & $\begin{array}{l}0.009 * * * \\
(0.001)\end{array}$ & $\begin{array}{l}0.007 \\
(0.286)\end{array}$ \\
\hline $\operatorname{lgdpc}=\operatorname{Ln}($ GDP per capita $)$ & $\begin{array}{l}-1.285^{*} \\
(0.093)\end{array}$ & $\begin{array}{l}-16.980^{* * *} \\
(0.000)\end{array}$ & $\begin{array}{l}-18.777^{* * *} \\
(0.000)\end{array}$ & $\begin{array}{l}-15.603^{* * *} \\
(0.000)\end{array}$ & $\begin{array}{l}-14.004^{* * *} \\
(0.000)\end{array}$ & $\begin{array}{l}-0.651^{* * *} \\
(0.002)\end{array}$ & $\begin{array}{l}-10.134^{* * *} \\
(0.000)\end{array}$ & $\begin{array}{l}6.290^{*} \\
(0.098)\end{array}$ & $\begin{array}{l}2.409 \\
(0.266)\end{array}$ \\
\hline $\lg \mathrm{dpc} \times \operatorname{lgdpc}$ & $\begin{array}{l}0.158^{* * *} \\
(0.002)\end{array}$ & $\begin{array}{l}0.941^{* * *} \\
(0.000)\end{array}$ & $\begin{array}{l}1.069^{* * *} \\
(0.000)\end{array}$ & $\begin{array}{l}0.735^{* * *} \\
(0.000)\end{array}$ & $\begin{array}{l}0.615^{* * *} \\
(0.008)\end{array}$ & $\begin{array}{l}0.145^{* * *} \\
(0.000)\end{array}$ & $\begin{array}{l}0.857^{* * *} \\
(0.000)\end{array}$ & $\begin{array}{c}-0.469^{*} \\
(0.079)\end{array}$ & $\begin{array}{l}-0.212 \\
(0.180)\end{array}$ \\
\hline Inflation & $\begin{array}{l}-0.002^{* * *} \\
(0.000)\end{array}$ & $\begin{array}{l}-0.004^{* * *} \\
(0.000)\end{array}$ & $\begin{array}{l}-0.004^{* * *} \\
(0.000)\end{array}$ & $\begin{array}{l}-0.004^{* * *} \\
(0.000)\end{array}$ & $\begin{array}{l}-0.004^{* * *} \\
(0.000)\end{array}$ & $\begin{array}{l}-0.004^{* * *} \\
(0.000)\end{array}$ & $\begin{array}{l}-0.006^{* * *} \\
(0.000)\end{array}$ & $\begin{array}{l}-0.001 \\
(0.506)\end{array}$ & $\begin{array}{l}-0.002 \\
(0.187)\end{array}$ \\
\hline Fixed Investment/GDP & $\begin{array}{l}0.132^{* * *} \\
(0.000)\end{array}$ & $\begin{array}{l}0.315^{* * *} \\
(0.000)\end{array}$ & $\begin{array}{l}0.314^{* * *} \\
(0.000)\end{array}$ & $\begin{array}{l}0.342^{* * *} \\
(0.000)\end{array}$ & $\begin{array}{l}0.362^{* * *} \\
(0.000)\end{array}$ & $\begin{array}{l}-0.011 \\
(0.300)\end{array}$ & $\begin{array}{l}-0.022^{* * *} \\
(0.000)\end{array}$ & $\begin{array}{l}0.070 * * * \\
(0.000)\end{array}$ & $\begin{array}{l}0.078^{* * *} \\
(0.000)\end{array}$ \\
\hline Ln ( $1+$ phones $)$ & $\begin{array}{l}0.992^{* * *} \\
(0.000)\end{array}$ & $\begin{array}{l}2.526^{* * * *} \\
(0.000)\end{array}$ & $\begin{array}{l}2.140^{* * *} \\
(0.000)\end{array}$ & $\begin{array}{l}3.043^{* * *} \\
(0.000)\end{array}$ & $\begin{array}{l}2.647^{* * *} \\
(0.000)\end{array}$ & $\begin{array}{l}0.752^{* * *} \\
(0.000)\end{array}$ & $\begin{array}{l}1.506^{* * *} \\
(0.000)\end{array}$ & $\begin{array}{l}0.262 \\
(0.589)\end{array}$ & $\begin{array}{l}0.448 \\
(0.373)\end{array}$ \\
\hline Constant & $\begin{array}{l}-2.022 \\
(0.480)\end{array}$ & $\begin{array}{l}62.580^{* * *} \\
(0.000)\end{array}$ & $\begin{array}{l}69.858^{* * *} \\
(0.000)\end{array}$ & $\begin{array}{l}60.481^{* * *} \\
(0.000)\end{array}$ & $\begin{array}{l}55.644^{* * *} \\
(0.000)\end{array}$ & $\begin{array}{l}0.000 \\
\mathrm{~N} / \mathrm{A}\end{array}$ & $\begin{array}{l}29.591^{* * *} \\
(0.000)\end{array}$ & $\begin{array}{l}-22.282^{*} \\
(0.0889)\end{array}$ & $\begin{array}{l}-7.744 \\
(0.264)\end{array}$ \\
\hline Hansen J Test (p-value $)^{1}$ & 0.259 & 0.473 & 0.507 & 0.671 & 0.422 & $\mathrm{~N} / \mathrm{A}$ & 0.392 & 1.000 & 0.647 \\
\hline Serial Correlation Test (p-value $)^{2}$ & 0.146 & 0.544 & 0.537 & 0.520 & 0.494 & $\mathrm{~N} / \mathrm{A}$ & 0.510 & 0.173 & 0.253 \\
\hline Number of Observations & 574 & 479 & 479 & 461 & 461 & 191 & 191 & 173 & 173 \\
\hline Number of Countries, $n$ & 96 & 77 & 77 & 75 & 75 & 37 & 37 & 35 & 35 \\
\hline Number of Instruments, $i$ & 82 & 82 & 72 & 82 & 54 & 80 & 37 & 81 & 28 \\
\hline Instrument ratio, $r=n / i$ & 1.17 & 0.94 & 1.07 & 0.91 & 1.39 & 0.46 & 1.00 & 0.43 & 1.25 \\
\hline $\begin{array}{l}\text { Limit the no.of lags of dependent } \\
\text { variable used in instrumentation? }\end{array}$ & No & No & Yes, 7 & No & Yes, 4 & No & Yes, 2 & No & Yes, 1 \\
\hline
\end{tabular}


Table 5: Robustness Regressions. FDI Risk, Institutional Quality and Political Risk

\begin{tabular}{|c|c|c|c|c|c|c|c|c|}
\hline \multirow{5}{*}{ VARIABLES } & \multicolumn{4}{|c|}{ Difference GMM } & \multicolumn{4}{|c|}{ System GMM } \\
\hline & $(1)$ & $(2)$ & $(3)$ & $(4)$ & $(5)$ & $(6)$ & $(7)$ & $(8)$ \\
\hline & Include & Include & Include & Include & Include & Include & Include & Include \\
\hline & FDI & Institutional & Political & All & FDI & Institutional & Political & All \\
\hline & Restrictions & Quality & Risk & Variables & Restrictions & Quality & Risk & Variables \\
\hline dem, $\widehat{\alpha}$ & $\begin{array}{c}3.572^{* * *} \\
(0.000)\end{array}$ & $\begin{array}{c}3.894^{* * *} \\
(0.000)\end{array}$ & $\begin{array}{c}3.816^{* * * *} \\
(0.000)\end{array}$ & $\begin{array}{c}3.644^{* * *} \\
(0.000)\end{array}$ & $\begin{array}{c}3.784^{* * *} \\
(0.000)\end{array}$ & $\begin{array}{c}4.238^{* * *} \\
(0.000)\end{array}$ & $\begin{array}{c}4.272^{* * *} \\
(0.000)\end{array}$ & $\begin{array}{c}4.294^{* * *} \\
(0.000)\end{array}$ \\
\hline Natural Resources, nat & $\begin{array}{c}-0.012^{* *} \\
(0.038)\end{array}$ & $\begin{array}{c}-0.012^{* *} \\
(0.023)\end{array}$ & $\begin{array}{c}-0.012^{* *} \\
(0.029)\end{array}$ & $\begin{array}{l}-0.004 \\
(0.495)\end{array}$ & $\begin{array}{l}-0.003 \\
(0.269)\end{array}$ & $\begin{array}{l}-0.001 \\
(0.833)\end{array}$ & $\begin{array}{l}-0.001 \\
(0.708)\end{array}$ & $\begin{array}{c}0.005 * * \\
(0.034)\end{array}$ \\
\hline nat $\times \operatorname{dem}, \widehat{\beta}$ & $\begin{array}{c}-0.068^{* * *} \\
(0.000)\end{array}$ & $\begin{array}{c}-0.070^{* * *} \\
(0.000)\end{array}$ & $\begin{array}{c}-0.075^{* * *} \\
(0.000)\end{array}$ & $\begin{array}{c}-0.070 * * * \\
(0.000)\end{array}$ & $\begin{array}{c}-0.070^{* * *} \\
(0.000)\end{array}$ & $\begin{array}{c}-0.077^{* * *} \\
(0.000)\end{array}$ & $\begin{array}{c}-0.082^{* * *} \\
(0.000)\end{array}$ & $\begin{array}{c}-0.083^{* * *} \\
(0.000)\end{array}$ \\
\hline Lagged FDI/GDP & $\begin{array}{c}-0.270 * * * \\
(0.000)\end{array}$ & $\begin{array}{c}-0.235^{* * *} \\
(0.000)\end{array}$ & $\begin{array}{c}-0.236 * * * \\
(0.000)\end{array}$ & $\begin{array}{c}-0.297^{* * *} \\
(0.000)\end{array}$ & $\begin{array}{c}-0.135^{* * *} \\
(0.000)\end{array}$ & $\begin{array}{c}-0.118^{* * *} \\
(0.000)\end{array}$ & $\begin{array}{c}-0.126^{* * *} \\
(0.000)\end{array}$ & $\begin{array}{c}-0.152^{* * *} \\
(0.000)\end{array}$ \\
\hline Trade/GDP & $\begin{array}{c}0.015^{* * *} \\
(0.000)\end{array}$ & $\begin{array}{c}0.013^{* * *} \\
(0.000)\end{array}$ & $\begin{array}{c}0.014^{* * *} \\
(0.000)\end{array}$ & $\begin{array}{c}0.016^{* * *} \\
(0.000)\end{array}$ & $\begin{array}{c}-0.006^{* * *} \\
(0.000)\end{array}$ & $\begin{array}{c}-0.008^{* * *} \\
(0.000)\end{array}$ & $\begin{array}{c}-0.004^{* * *} \\
(0.000)\end{array}$ & $\begin{array}{l}-0.001 \\
(0.310)\end{array}$ \\
\hline $\operatorname{lgdpc}=\operatorname{Ln}($ GDP per capita $)$ & $\begin{array}{c}-7.976 * * * \\
(0.000)\end{array}$ & $\begin{array}{c}-9.897^{* * *} \\
(0.000)\end{array}$ & $\begin{array}{c}-9.818^{* * *} \\
(0.000)\end{array}$ & $\begin{array}{c}-10.119^{* * *} \\
(0.000)\end{array}$ & $\begin{array}{c}0.166 \\
(0.873)\end{array}$ & $\begin{array}{c}-1.595^{* *} \\
(0.038)\end{array}$ & $\begin{array}{c}-1.525^{*} \\
(0.059)\end{array}$ & $\begin{array}{c}-2.839 * * \\
(0.034)\end{array}$ \\
\hline $\operatorname{lgdpc} \times \operatorname{lgdpc}$ & $\begin{array}{c}0.376^{* * *} \\
(0.003)\end{array}$ & $\begin{array}{c}0.577^{* * *} \\
(0.000)\end{array}$ & $\begin{array}{c}0.584^{* * *} \\
(0.000)\end{array}$ & $\begin{array}{c}0.555^{* * *} \\
(0.000)\end{array}$ & $\begin{array}{l}-0.007 \\
(0.917)\end{array}$ & $\begin{array}{c}0.137 * * * \\
(0.006)\end{array}$ & $\begin{array}{c}0.152^{* * *} \\
(0.002)\end{array}$ & $\begin{array}{c}0.235^{* * *} \\
(0.006)\end{array}$ \\
\hline inflation & $\begin{array}{c}-0.002^{* * *} \\
(0.000)\end{array}$ & $\begin{array}{c}-0.003^{* * *} \\
(0.000)\end{array}$ & $\begin{array}{c}-0.001^{* * *} \\
(0.000)\end{array}$ & $\begin{array}{c}-0.002^{* * *} \\
(0.000)\end{array}$ & $\begin{array}{l}-0.000 \\
(0.800)\end{array}$ & $\begin{array}{c}-0.000^{*} \\
(0.073)\end{array}$ & $\begin{array}{l}0.001 * * \\
(0.044)\end{array}$ & $\begin{array}{c}0.000 \\
(0.935)\end{array}$ \\
\hline Fixed investment/GDP & $\begin{array}{c}0.221^{* * *} \\
(0.000)\end{array}$ & $\begin{array}{c}0.223^{* * *} \\
(0.000)\end{array}$ & $\begin{array}{c}0.225^{* * * *} \\
(0.000)\end{array}$ & $\begin{array}{c}0.215^{* * *} \\
(0.000)\end{array}$ & $\begin{array}{c}0.223^{* * *} \\
(0.000)\end{array}$ & $\begin{array}{c}0.228^{* * *} \\
(0.000)\end{array}$ & $\begin{array}{c}0.233^{* * *} \\
(0.000)\end{array}$ & $\begin{array}{c}0.225^{* * *} \\
(0.000)\end{array}$ \\
\hline $\operatorname{Ln}(1+$ phones $)$ & $\begin{array}{c}1.797^{* * *} \\
(0.000)\end{array}$ & $\begin{array}{c}1.883^{* * * *} \\
(0.000)\end{array}$ & $\begin{array}{c}1.613^{* * *} \\
(0.000)\end{array}$ & $\begin{array}{c}1.649^{* * * *} \\
(0.000)\end{array}$ & $\begin{array}{c}2.290^{* * *} \\
(0.000)\end{array}$ & $\begin{array}{c}2.384^{* * *} \\
(0.000)\end{array}$ & $\begin{array}{c}2.085^{* * *} \\
(0.000)\end{array}$ & $\begin{array}{c}2.140^{* * *} \\
(0.000)\end{array}$ \\
\hline FDI Restrictions & $\begin{array}{c}-3.523^{* * *} \\
(0.000)\end{array}$ & & & $\begin{array}{c}-2.203^{* * *} \\
(0.000)\end{array}$ & $\begin{array}{c}-1.857^{* * *} \\
(0.000)\end{array}$ & & & $\begin{array}{c}-1.023^{* * *} \\
(0.000)\end{array}$ \\
\hline Corruption & & $\begin{array}{c}0.974 * * * \\
(0.004)\end{array}$ & & $\begin{array}{c}0.064 \\
(0.855)\end{array}$ & & $\begin{array}{l}-0.250 \\
(0.245)\end{array}$ & & $\begin{array}{c}-1.550 * * * \\
(0.000)\end{array}$ \\
\hline Rule of Law & & $\begin{array}{c}0.477 * * \\
(0.044)\end{array}$ & & $\begin{array}{l}0.541^{*} \\
(0.067)\end{array}$ & & $\begin{array}{c}0.098 \\
(0.644)\end{array}$ & & $\begin{array}{c}1.357^{* * *} \\
(0.000)\end{array}$ \\
\hline Bureaucracy & & $\begin{array}{c}-1.515^{* * *} \\
(0.000)\end{array}$ & & $\begin{array}{c}-1.639 * * * \\
(0.000)\end{array}$ & & $\begin{array}{l}-0.195 \\
(0.198)\end{array}$ & & $\begin{array}{c}-0.490 * * \\
(0.014)\end{array}$ \\
\hline Conflict & & & $\begin{array}{c}0.811^{* * *} \\
(0.003)\end{array}$ & $\begin{array}{c}1.780 * * * \\
(0.000)\end{array}$ & & & $\begin{array}{c}2.507 * * * \\
(0.000)\end{array}$ & $\begin{array}{c}4.012^{* * *} \\
(0.000)\end{array}$ \\
\hline Instability of Government & & & $\begin{array}{c}-2.801^{* * *} \\
(0.000)\end{array}$ & $\begin{array}{c}-1.731^{* * *} \\
(0.000)\end{array}$ & & & $\begin{array}{c}-2.440^{* * *} \\
(0.000)\end{array}$ & $\begin{array}{c}-2.040 * * * \\
(0.000)\end{array}$ \\
\hline Constant & $\begin{array}{c}32.425^{* * *} \\
(0.000)\end{array}$ & $\begin{array}{c}33.507^{* * *} \\
(0.000)\end{array}$ & $\begin{array}{c}34.114^{* * *} \\
(0.000)\end{array}$ & $\begin{array}{c}38.766^{* * *} \\
(0.000)\end{array}$ & $\begin{array}{c}-6.473^{*} \\
(0.090)\end{array}$ & $\begin{array}{l}-2.501 \\
(0.388)\end{array}$ & $\begin{array}{l}-3.459 \\
(0.300)\end{array}$ & $\begin{array}{c}1.817 \\
(0.725)\end{array}$ \\
\hline Hansen J Test (p-value) & 0.381 & 0.525 & 0.281 & 0.359 & 0.504 & 0.341 & 0.269 & 0.370 \\
\hline Serial Correlation Test (p-value) & 0.947 & 0.812 & 0.807 & 0.961 & 0.627 & 0.591 & 0.626 & 0.643 \\
\hline Number of Observations & 455 & 455 & 455 & 455 & 551 & 551 & 551 & 551 \\
\hline Number of Countries, $n$ & 86 & 86 & 86 & 86 & 87 & 87 & 87 & 87 \\
\hline Number of Instruments, $i$ & 71 & 73 & 72 & 76 & 80 & 82 & 81 & 85 \\
\hline Instrument ratio, $r=n / i$ & 1.21 & 1.18 & 1.19 & 1.13 & 1.09 & 1.06 & 1.07 & 1.02 \\
\hline $\begin{array}{l}\text { Limit the no.of lags of dependent } \\
\text { variable used in instrumentation? }\end{array}$ & No & No & No & No & No & No & No & No \\
\hline
\end{tabular}


Table 6: Robustness Regressions. Sub-Periods

\begin{tabular}{|c|c|c|c|c|c|c|}
\hline \multirow[b]{3}{*}{ VARIABLES } & \multicolumn{3}{|c|}{ Difference GMM } & \multicolumn{3}{|c|}{ Systems GMM } \\
\hline & $(1)$ & $(2)$ & $(3)$ & $(4)$ & $(5)$ & (6) \\
\hline & 1982-1992 & $1992-2007$ & $1970-2007$ & 1982-1992 & $1992-2007$ & $1970-2007$ \\
\hline $\operatorname{dem}, \widehat{\alpha}$ & $\begin{array}{c}0.884^{* *} \\
(0.018)\end{array}$ & $\begin{array}{c}2.631^{* * *} \\
(0.000)\end{array}$ & $\begin{array}{c}2.463^{* * *} \\
(0.000)\end{array}$ & $\begin{array}{c}1.219^{* * *} \\
(0.003)\end{array}$ & $\begin{array}{c}1.689^{* * *} \\
(0.000)\end{array}$ & $\begin{array}{c}2.218^{* * *} \\
(0.000)\end{array}$ \\
\hline Natural Resources, nat & $\begin{array}{c}0.008 \\
(0.372)\end{array}$ & $\begin{array}{c}-0.022^{* *} \\
(0.021)\end{array}$ & $\begin{array}{l}-0.009 \\
(0.111)\end{array}$ & $\begin{array}{c}0.010 \\
(0.202)\end{array}$ & $\begin{array}{c}-0.020^{* *} \\
(0.013)\end{array}$ & $\begin{array}{c}-0.012^{* * *} \\
(0.004)\end{array}$ \\
\hline nat $\times \operatorname{dem}, \widehat{\beta}$ & $\begin{array}{c}-0.035^{* * *} \\
(0.000)\end{array}$ & $\begin{array}{c}-0.034^{* * *} \\
(0.009)\end{array}$ & $\begin{array}{c}-0.050 * * * \\
(0.000)\end{array}$ & $\begin{array}{c}-0.045^{* * *} \\
(0.000)\end{array}$ & $\begin{array}{c}-0.027^{* * *} \\
(0.008)\end{array}$ & $\begin{array}{c}-0.049^{* * *} \\
(0.000)\end{array}$ \\
\hline \multicolumn{7}{|l|}{ Other Variables } \\
\hline Lagged FDI/GDP & $\begin{array}{c}0.172^{* * *} \\
(0.000)\end{array}$ & $\begin{array}{c}-0.248^{* * *} \\
(0.000)\end{array}$ & $\begin{array}{c}-0.192 * * * \\
(0.000)\end{array}$ & $\begin{array}{c}0.290 * * * \\
(0.000)\end{array}$ & $\begin{array}{c}-0.099^{* * *} \\
(0.000)\end{array}$ & $\begin{array}{c}-0.054^{* * *} \\
(0.000)\end{array}$ \\
\hline Trade/GDP & $\begin{array}{c}0.035^{* * *} \\
(0.000)\end{array}$ & $\begin{array}{c}0.021^{* * *} \\
(0.000)\end{array}$ & $\begin{array}{c}0.023^{* * *} \\
(0.000)\end{array}$ & $\begin{array}{c}0.020 * * * \\
(0.000)\end{array}$ & $\begin{array}{c}0.014^{* * *} \\
(0.000)\end{array}$ & $\begin{array}{c}0.020^{* * *} \\
(0.000)\end{array}$ \\
\hline $\operatorname{lgdpc}=\operatorname{Ln}($ GDP per capita $)$ & $\begin{array}{c}6.023 \\
(0.144)\end{array}$ & $\begin{array}{l}-4.965 \\
(0.271)\end{array}$ & $\begin{array}{l}-2.151 \\
(0.324)\end{array}$ & $\begin{array}{l}7.480^{*} \\
(0.069)\end{array}$ & $\begin{array}{c}6.149 * * \\
(0.024)\end{array}$ & $\begin{array}{c}0.964 \\
(0.434)\end{array}$ \\
\hline $\operatorname{lgdpc} \times \operatorname{lgdpc}$ & $\begin{array}{c}-0.544^{*} \\
(0.070)\end{array}$ & $\begin{array}{c}0.234 \\
(0.432)\end{array}$ & $\begin{array}{c}0.042 \\
(0.768)\end{array}$ & $\begin{array}{c}-0.704^{* *} \\
(0.018)\end{array}$ & $\begin{array}{c}-0.499 * * * \\
(0.006)\end{array}$ & $\begin{array}{c}-0.195^{* *} \\
(0.019)\end{array}$ \\
\hline Inflation & $\begin{array}{c}-0.001^{* * *} \\
(0.000)\end{array}$ & $\begin{array}{c}-0.006^{* * *} \\
(0.00)\end{array}$ & $\begin{array}{c}-0.004^{* * *} \\
(0.000)\end{array}$ & $\begin{array}{c}-0.001^{* * *} \\
(0.003)\end{array}$ & $\begin{array}{c}-0.004^{* * *} \\
(0.000)\end{array}$ & $\begin{array}{c}-0.003^{* * *} \\
(0.000)\end{array}$ \\
\hline Fixed Investment/GDP & $\begin{array}{c}0.095^{* * *} \\
(0.000)\end{array}$ & $\begin{array}{c}0.264^{* * *} \\
(0.000)\end{array}$ & $\begin{array}{c}0.198^{* * *} \\
(0.000)\end{array}$ & $\begin{array}{c}0.135 * * * \\
(0.000)\end{array}$ & $\begin{array}{c}0.272^{* * *} \\
(0.000)\end{array}$ & $\begin{array}{c}0.214^{* * *} \\
(0.000)\end{array}$ \\
\hline Ln $(1+$ phones $)$ & $\begin{array}{c}1.445^{* * *} \\
(0.000)\end{array}$ & $\begin{array}{c}2.040^{* * *} \\
(0.000)\end{array}$ & $\begin{array}{c}1.862^{* * *} \\
(0.000)\end{array}$ & $\begin{array}{c}1.456^{* * *} \\
(0.000)\end{array}$ & $\begin{array}{c}2.367^{* * *} \\
(0.000)\end{array}$ & $\begin{array}{c}2.388^{* * *} \\
(0.000)\end{array}$ \\
\hline Constant & $\begin{array}{c}-19.673 \\
(0.172)\end{array}$ & $\begin{array}{l}14.877 \\
(0.378)\end{array}$ & $\begin{array}{c}6.378 \\
(0.440)\end{array}$ & $\begin{array}{c}-22.264 \\
(0.125)\end{array}$ & $\begin{array}{c}-26.205^{* * *} \\
(0.010)\end{array}$ & $\begin{array}{l}-4.506 \\
(0.310)\end{array}$ \\
\hline Hansen J Test (p-value) & 0.072 & 0.123 & 0.325 & 0.234 & 0.237 & 0.563 \\
\hline Serial Correlation Test (p-value) & 0.177 & 0.636 & 0.586 & 0.221 & 0.406 & 0.471 \\
\hline Number of Observations & 179 & 435 & 633 & 213 & 504 & 771 \\
\hline Number of Countries, $n$ & 57 & 105 & 107 & 73 & 111 & 113 \\
\hline Number of Instruments, $i$ & 28 & 61 & 76 & 32 & 60 & 87 \\
\hline Instrument ratio, $r=n / i$ & 2.04 & 1.72 & 1.41 & 2.28 & 1.85 & 1.30 \\
\hline $\begin{array}{l}\text { Limit the no.of lags of dependent } \\
\text { variable used in instrumentation? }\end{array}$ & No & No & No & No & No & No \\
\hline
\end{tabular}


Table 7: Robustness Regressions. Alternative Measures of Democracy

\begin{tabular}{|c|c|c|c|c|}
\hline & \multicolumn{2}{|c|}{ Difference GMM } & \multicolumn{2}{|c|}{ System GMM } \\
\hline & $\begin{array}{c}\text { (1) } \\
\text { Principal } \\
\text { Componet }\end{array}$ & $\begin{array}{c}(2) \\
\text { Average } \\
\text { Democracy }\end{array}$ & $\begin{array}{c}(3) \\
\text { Principal } \\
\text { Component }\end{array}$ & $\begin{array}{c}(4) \\
\text { Average } \\
\text { Democracy }\end{array}$ \\
\hline $\operatorname{dem}, \widehat{\alpha}$ & $\begin{array}{c}1.126^{* * *} \\
(0.000)\end{array}$ & $\begin{array}{c}5.717^{* * *} \\
(0.000)\end{array}$ & $\begin{array}{c}1.152^{* * *} \\
(0.000)\end{array}$ & $\begin{array}{c}5.848^{* * *} \\
(0.000)\end{array}$ \\
\hline Natural Resources, nat & $\begin{array}{c}-0.056^{* * *} \\
(0.000)\end{array}$ & $\begin{array}{c}0.005 \\
(0.457)\end{array}$ & $\begin{array}{c}-0.049 * * * \\
(0.000)\end{array}$ & $\begin{array}{c}0.010^{* * *} \\
(0.002)\end{array}$ \\
\hline nat $\times$ dem,$\widehat{\beta}$ & $\begin{array}{c}-0.020^{* * *} \\
(0.000)\end{array}$ & $\begin{array}{c}-0.100^{* * *} \\
(0.000)\end{array}$ & $\begin{array}{c}-0.019 * * * \\
(0.000)\end{array}$ & $\begin{array}{c}-0.097^{* * *} \\
(0.000)\end{array}$ \\
\hline Other variables & & & & \\
\hline Lagged FDI/GDP & $\begin{array}{c}-0.220^{* * *} \\
(0.000)\end{array}$ & $\begin{array}{c}-0.217^{* * *} \\
(0.000)\end{array}$ & $\begin{array}{c}-0.098^{* * *} \\
(0.000)\end{array}$ & $\begin{array}{c}-0.095^{* * *} \\
(0.000)\end{array}$ \\
\hline Trade/GDP & $\begin{array}{c}0.015^{* * * *} \\
(0.000)\end{array}$ & $\begin{array}{c}0.014^{* * *} \\
(0.000)\end{array}$ & $\begin{array}{c}-0.007^{* * *} \\
(0.000)\end{array}$ & $\begin{array}{c}-0.008^{* * *} \\
(0.000)\end{array}$ \\
\hline $\operatorname{lgdpc}=\operatorname{Ln}($ GDP per capita $)$ & $\begin{array}{c}-10.494^{* * *} \\
(0.000)\end{array}$ & $\begin{array}{c}-10.469^{* * *} \\
(0.000)\end{array}$ & $\begin{array}{l}-0.932 \\
(0.307)\end{array}$ & $\begin{array}{l}-1.049 \\
(0.252)\end{array}$ \\
\hline $\operatorname{lgdpc} \times \operatorname{lgdpc}$ & $\begin{array}{c}0.614^{* * * *} \\
(0.000)\end{array}$ & $\begin{array}{c}0.614^{* * *} \\
(0.000)\end{array}$ & $\begin{array}{l}0.099^{*} \\
(0.096)\end{array}$ & $\begin{array}{l}0.107^{*} \\
(0.073)\end{array}$ \\
\hline inflation & $\begin{array}{c}-0.002^{* * *} \\
(0.000)\end{array}$ & $\begin{array}{c}-0.002^{* * *} \\
(0.000)\end{array}$ & $\begin{array}{l}-0.000 \\
(0.104)\end{array}$ & $\begin{array}{c}-0.001^{*} \\
(0.066)\end{array}$ \\
\hline Fixed investment/GDP & $\begin{array}{c}0.223^{* * *} \\
(0.000)\end{array}$ & $\begin{array}{c}0.224^{* * *} \\
(0.000)\end{array}$ & $\begin{array}{c}0.240^{* * *} \\
(0.000)\end{array}$ & $\begin{array}{c}0.241^{* * *} \\
(0.000)\end{array}$ \\
\hline Ln $(1+$ phones $)$ & $\begin{array}{c}1.829 * * * \\
(0.000)\end{array}$ & $\begin{array}{c}1.848^{* * *} \\
(0.000)\end{array}$ & $\begin{array}{c}2.093^{* * *} \\
(0.000)\end{array}$ & $\begin{array}{c}2.115^{* * *} \\
(0.000)\end{array}$ \\
\hline Constant & $\begin{array}{c}38.072^{* * *} \\
(0.000)\end{array}$ & $\begin{array}{c}34.384^{* * *} \\
(0.000)\end{array}$ & $\begin{array}{l}-2.748 \\
(0.430)\end{array}$ & $\begin{array}{c}-5.922^{*} \\
(0.092)\end{array}$ \\
\hline Hansen J Test (p-value) & 0.448 & 0.464 & 0.320 & 0.339 \\
\hline Serial Correlation Test (p-value) & 0.774 & 0.769 & 0.597 & 0.593 \\
\hline Number of Observations & 452 & 452 & 547 & 547 \\
\hline Number of Countries, $n$ & 86 & 86 & 86 & 86 \\
\hline Number of Instruments, $i$ & 70 & 70 & 79 & 79 \\
\hline Instrument ratio, $r=n / i$ & 1.23 & 1.23 & 1.09 & 1.09 \\
\hline $\begin{array}{l}\text { Limit the no.of lags of dependent } \\
\text { variable used in instrumentation? }\end{array}$ & No & No & No & No \\
\hline
\end{tabular}


Table 8: Robustness Regressions. Time Fixed Effects and FDI per Capita as Dependent Variables

\begin{tabular}{|c|c|c|c|c|}
\hline \multirow[b]{2}{*}{ Variables } & \multicolumn{2}{|c|}{ FDI Per Capita } & \multicolumn{2}{|c|}{ Time Fixed Effects } \\
\hline & $\begin{array}{c}(1) \\
\text { Difference }\end{array}$ & $\begin{array}{c}(2) \\
\text { System }\end{array}$ & $\begin{array}{c}(3) \\
\text { Difference }\end{array}$ & $\begin{array}{c}(4) \\
\text { System }\end{array}$ \\
\hline dem, $\widehat{\alpha}$ & $\begin{array}{c}6.355^{* * *} \\
(0.000)\end{array}$ & $\begin{array}{c}7.130 * * * \\
(0.000)\end{array}$ & $\begin{array}{c}2.128^{* * * *} \\
(0.000)\end{array}$ & $\begin{array}{c}2.177^{* * * *} \\
(0.000)\end{array}$ \\
\hline Natural Resources, nat & $\begin{array}{c}0.021^{* * *} \\
(0.000)\end{array}$ & $\begin{array}{c}0.028^{* * *} \\
(0.000)\end{array}$ & $\begin{array}{c}-0.027^{* * *} \\
(0.000)\end{array}$ & $\begin{array}{c}-0.023^{* * *} \\
(0.000)\end{array}$ \\
\hline nat $\times$ dem, $\widehat{\beta}$ & $\begin{array}{c}-0.196^{* * *} \\
(0.000)\end{array}$ & $\begin{array}{c}-0.207^{* * *} \\
(0.000)\end{array}$ & $\begin{array}{c}-0.032^{* * *} \\
(0.000)\end{array}$ & $\begin{array}{c}-0.038^{* * *} \\
(0.000)\end{array}$ \\
\hline Lagged FDI/GDP & & & $\begin{array}{c}-0.280^{* * *} \\
(0.000)\end{array}$ & $\begin{array}{c}-0.073^{* * *} \\
(0.000)\end{array}$ \\
\hline Trade/GDP & $\begin{array}{c}0.022^{* * *} \\
(0.000)\end{array}$ & $\begin{array}{c}0.058^{* * *} \\
(0.000)\end{array}$ & $\begin{array}{c}0.017^{* * * *} \\
(0.000)\end{array}$ & $\begin{array}{c}0.023^{* * *} \\
(0.000)\end{array}$ \\
\hline $\operatorname{lgdpc}=\operatorname{Ln}($ GDP per capita $)$ & $\begin{array}{c}-85.243^{* * *} \\
(0.000)\end{array}$ & $\begin{array}{c}-78.318^{* * *} \\
(0.000)\end{array}$ & $\begin{array}{l}-3.597 \\
(0.189)\end{array}$ & $\begin{array}{c}0.256 \\
(0.851)\end{array}$ \\
\hline $\operatorname{lgdpc} \times \operatorname{lgdpc}$ & $\begin{array}{c}6.378^{* * *} \\
(0.000)\end{array}$ & $\begin{array}{c}5.597^{* * *} \\
(0.000)\end{array}$ & $\begin{array}{c}0.007 \\
(0.969)\end{array}$ & $\begin{array}{l}-0.142 \\
(0.122)\end{array}$ \\
\hline inflation & $\begin{array}{c}-0.002^{* *} \\
(0.028)\end{array}$ & $\begin{array}{c}-0.003^{* *} \\
(0.039)\end{array}$ & $\begin{array}{c}-0.003^{* * *} \\
(0.000)\end{array}$ & $\begin{array}{c}-0.003^{* * *} \\
(0.000)\end{array}$ \\
\hline Fixed investment/GDP & $\begin{array}{c}0.427^{* * *} \\
(0.000)\end{array}$ & $\begin{array}{c}0.534^{* * *} \\
(0.000)\end{array}$ & $\begin{array}{c}0.250^{* * *} \\
(0.000)\end{array}$ & $\begin{array}{c}0.265^{* * *} \\
(0.000)\end{array}$ \\
\hline Ln $(1+$ phones $)$ & $\begin{array}{c}3.194^{* * *} \\
(0.000)\end{array}$ & $\begin{array}{c}6.085^{* * *} \\
(0.000)\end{array}$ & $\begin{array}{c}0.373 \\
(0.178)\end{array}$ & $\begin{array}{c}1.520^{* * *} \\
(0.000)\end{array}$ \\
\hline $\begin{array}{l}\text { Time Fixed Effect } \\
\text { L.fdinpop_10 }\end{array}$ & $\begin{array}{c}0.133^{* * *} \\
(0.000)\end{array}$ & $\begin{array}{c}0.324^{* * *} \\
(0.000)\end{array}$ & Yes & Yes \\
\hline Constant & $\begin{array}{c}264.588^{* * *} \\
(0.000)\end{array}$ & $\begin{array}{c}244.335^{* * *} \\
(0.000)\end{array}$ & $\begin{array}{l}18.720^{*} \\
(0.059)\end{array}$ & $\begin{array}{l}-2.441 \\
(0.613)\end{array}$ \\
\hline Hansen J Test (p-value) & 0.104 & 0.214 & 0.190 & 0.197 \\
\hline Serial Correlation Test (p-value) & 0.199 & 0.192 & 0.762 & 0.524 \\
\hline Number of Observations & 434 & 520 & 566 & 652 \\
\hline Number of Countries, $n$ & 97 & 107 & 106 & 112 \\
\hline Number of Instruments, $i$ & 73 & 82 & 82 & 91 \\
\hline Instrument ratio, $r=n / i$ & 1.33 & 1.30 & 1.29 & 1.23 \\
\hline $\begin{array}{l}\text { Limit the no.of lags of dependent } \\
\text { variable used in instrumentation? }\end{array}$ & No & No & No & No \\
\hline
\end{tabular}


Table 9: Robustness Regressions. Endogenous Democracy and Natural Resources

\begin{tabular}{|c|c|c|c|c|c|c|c|c|}
\hline \multirow[b]{2}{*}{ Variables } & \multicolumn{4}{|c|}{ Difference GMM } & \multicolumn{4}{|c|}{ System GMM } \\
\hline & $\begin{array}{l}\text { (1) } \\
\text { dem is } \\
\text { endogenous }\end{array}$ & $\begin{array}{c}(2) \\
\text { dem \& nat } \\
\text { endogenous }\end{array}$ & $\begin{array}{l}\text { (3) } \\
\text { dem is } \\
\text { endogenous }\end{array}$ & $\begin{array}{c}\text { (4) } \\
\text { dem \& nat } \\
\text { endogenous }\end{array}$ & $\begin{array}{l}\quad(5) \\
\text { dem is } \\
\text { endogenous }\end{array}$ & $\begin{array}{c}(6) \\
\text { dem \& nat } \\
\text { endogenous }\end{array}$ & $\begin{array}{l}\text { (7) } \\
\text { dem is } \\
\text { endogenous }\end{array}$ & $\begin{array}{c}\text { (8) } \\
\text { dem \& nat } \\
\text { endogenous }\end{array}$ \\
\hline dem, $\widehat{\alpha}$ & $\begin{array}{l}3.982^{* * *} \\
(0.000)\end{array}$ & $\begin{array}{l}2.474^{* * *} \\
(0.000)\end{array}$ & $\begin{array}{l}3.775^{* * *} \\
(0.000)\end{array}$ & $\begin{array}{l}3.563^{* * *} \\
(0.000)\end{array}$ & $\begin{array}{l}1.769^{* * *} \\
(0.000)\end{array}$ & $\begin{array}{l}1.601^{* * *} \\
(0.000)\end{array}$ & $\begin{array}{l}1.338^{* * *} \\
(0.000)\end{array}$ & $\begin{array}{l}1.558^{* * *} \\
(0.000)\end{array}$ \\
\hline Natural Resources, nat & $\begin{array}{l}-0.007^{* * *} \\
(0.000)\end{array}$ & $\begin{array}{l}-0.026^{* * *} \\
(0.000)\end{array}$ & $\begin{array}{l}0.008 \\
(0.158)\end{array}$ & $\begin{array}{l}0.014^{* * *} \\
(0.000)\end{array}$ & $\begin{array}{l}0.001 \\
(0.337)\end{array}$ & $\begin{array}{l}0.019^{* * *} \\
(0.000)\end{array}$ & $\begin{array}{l}-0.001 \\
(0.548)\end{array}$ & $\begin{array}{l}0.026^{* * *} \\
(0.000)\end{array}$ \\
\hline nat $\times \operatorname{dem}, \widehat{\beta}$ & $\begin{array}{l}-0.092^{* * *} \\
(0.000)\end{array}$ & $\begin{array}{l}-0.062^{* * *} \\
(0.000)\end{array}$ & $\begin{array}{l}-0.107^{* * *} \\
(0.000)\end{array}$ & $\begin{array}{l}-0.107^{* * *} \\
(0.000)\end{array}$ & $\begin{array}{l}-0.036^{* * *} \\
(0.000)\end{array}$ & $\begin{array}{l}-0.048^{* * *} \\
(0.000)\end{array}$ & $\begin{array}{l}-0.027^{* * *} \\
(0.000)\end{array}$ & $\begin{array}{l}-0.046^{* * *} \\
(0.000)\end{array}$ \\
\hline Other Variables & & & & & & & & \\
\hline Lagged FDI/GDP & $\begin{array}{l}-0.111^{* * *} \\
(0.000)\end{array}$ & $\begin{array}{l}-0.103^{* * *} \\
(0.000)\end{array}$ & $\begin{array}{l}-0.161^{* * *} \\
(0.000)\end{array}$ & $\begin{array}{l}-0.177^{* * *} \\
(0.000)\end{array}$ & $\begin{array}{l}-0.014^{* * *} \\
(0.000)\end{array}$ & $\begin{array}{l}0.006 * * * \\
(0.006)\end{array}$ & $\begin{array}{l}-0.034^{* * *} \\
(0.000)\end{array}$ & $\begin{array}{l}0.003 \\
(0.518)\end{array}$ \\
\hline Trade/GDP & $\begin{array}{l}0.028^{* * *} \\
(0.000)\end{array}$ & $\begin{array}{l}0.024^{* * *} \\
(0.000)\end{array}$ & $\begin{array}{l}0.023^{* * *} \\
(0.000)\end{array}$ & $\begin{array}{l}0.024^{* * *} \\
(0.000)\end{array}$ & $\begin{array}{l}0.010^{* * *} \\
(0.000)\end{array}$ & $\begin{array}{l}0.004^{* * *} \\
(0.000)\end{array}$ & $\begin{array}{l}0.010^{* * *} \\
(0.000)\end{array}$ & $\begin{array}{l}0.001^{*} \\
(0.069)\end{array}$ \\
\hline $\operatorname{lgdpc}=\operatorname{Ln}($ GDP per capita $)$ & $\begin{array}{l}-14.905^{* * *} \\
(0.000)\end{array}$ & $\begin{array}{l}-15.124^{* * *} \\
(0.000)\end{array}$ & $\begin{array}{l}-8.711^{* * *} \\
(0.000)\end{array}$ & $\begin{array}{l}-11.832^{* * *} \\
(0.000)\end{array}$ & $\begin{array}{l}-3.363^{* * *} \\
(0.000)\end{array}$ & $\begin{array}{l}-5.916^{* * *} \\
(0.000)\end{array}$ & $\begin{array}{l}-1.122^{* * *} \\
(0.005)\end{array}$ & $\begin{array}{l}-3.704^{* * *} \\
(0.000)\end{array}$ \\
\hline $\operatorname{lgdpc} \times \operatorname{lgdpc}$ & $\begin{array}{l}0.993^{* * *} \\
(0.000)\end{array}$ & $\begin{array}{l}0.998^{* * *} \\
(0.000)\end{array}$ & $\begin{array}{l}0.505^{* * *} \\
(0.000)\end{array}$ & $\begin{array}{l}0.716^{* * *} \\
(0.000)\end{array}$ & $\begin{array}{l}0.199 * * * \\
(0.000)\end{array}$ & $\begin{array}{l}0.341^{* * *} \\
(0.000)\end{array}$ & $\begin{array}{l}0.005 \\
(0.848)\end{array}$ & $\begin{array}{l}0.156^{* * *} \\
(0.000)\end{array}$ \\
\hline inflation & $\begin{array}{l}-0.006 * * * \\
(0.000)\end{array}$ & $\begin{array}{l}-0.005^{* * *} \\
(0.000)\end{array}$ & $\begin{array}{l}-0.006^{* * *} \\
(0.000)\end{array}$ & $\begin{array}{l}-0.006 * * * \\
(0.000)\end{array}$ & $\begin{array}{l}-0.004^{* * *} \\
(0.000)\end{array}$ & $\begin{array}{l}-0.003^{* * *} \\
(0.000)\end{array}$ & $\begin{array}{l}-0.004^{* * *} \\
(0.000)\end{array}$ & $\begin{array}{l}-0.003^{* * *} \\
(0.000)\end{array}$ \\
\hline Fixed investment/GDP & $\begin{array}{l}0.226^{* * *} \\
(0.000)\end{array}$ & $\begin{array}{l}0.218^{* * *} \\
(0.000)\end{array}$ & $\begin{array}{l}0.244^{* * *} \\
(0.000)\end{array}$ & $\begin{array}{l}0.244^{* * *} \\
(0.000)\end{array}$ & $\begin{array}{l}0.219^{* * *} \\
(0.000)\end{array}$ & $\begin{array}{l}0.215^{* * *} \\
(0.000)\end{array}$ & $\begin{array}{l}0.239 * * * \\
(0.000)\end{array}$ & $\begin{array}{l}0.243^{* * *} \\
(0.000)\end{array}$ \\
\hline $\operatorname{Ln}(1+$ phones $)$ & $\begin{array}{l}1.192^{* * *} \\
(0.000)\end{array}$ & $\begin{array}{l}1.420^{* * *} \\
(0.000)\end{array}$ & $\begin{array}{l}1.656^{* * *} \\
(0.000)\end{array}$ & $\begin{array}{l}1.785^{* * *} \\
(0.000)\end{array}$ & $\begin{array}{l}1.806^{* * *} \\
(0.000)\end{array}$ & $\begin{array}{l}2.091^{* * *} \\
(0.000)\end{array}$ & $\begin{array}{l}2.163^{* * *} \\
(0.000)\end{array}$ & $\begin{array}{l}2.333^{* * *} \\
(0.000)\end{array}$ \\
\hline Constant & $\begin{array}{l}47.765^{* * *} \\
(0.000)\end{array}$ & $\begin{array}{l}49.916^{* * *} \\
(0.000)\end{array}$ & $\begin{array}{l}27.768^{* * *} \\
(0.000)\end{array}$ & $\begin{array}{l}38.964^{* * *} \\
(0.000)\end{array}$ & $\begin{array}{l}7.376^{* * *} \\
(0.000)\end{array}$ & $\begin{array}{l}17.842^{* * *} \\
(0.000)\end{array}$ & $\begin{array}{l}0.580 \\
(0.703)\end{array}$ & $\begin{array}{l}10.718^{* * *} \\
(0.000)\end{array}$ \\
\hline Hansen J Test (p-value $)^{1}$ & 1.000 & 1.000 & 0.472 & 0.357 & 1.000 & 1.000 & 0.526 & 0.322 \\
\hline Serial Correlation Test (p-value $)^{2}$ & 0.561 & 0.535 & 0.577 & 0.598 & 0.465 & 0.448 & 0.474 & 0.458 \\
\hline Number of Observations & 566 & 566 & 566 & 566 & 652 & 652 & 652 & 652 \\
\hline Number of Countries, $n$ & 106 & 106 & 106 & 106 & 112 & 112 & 112 & 112 \\
\hline Number of Instruments, $i$ & 197 & 259 & 89 & 97 & 224 & 295 & 110 & 105 \\
\hline Instrument ratio, $r=n / i$ & 0.57 & 0.41 & 1.19 & 1.09 & 0.50 & 0.38 & 1.02 & 1.07 \\
\hline $\begin{array}{l}\text { Limit the no.of lags of dependent } \\
\text { variable used in instrumentation? } \\
\text { Limit the no.of lags of endogenous }\end{array}$ & No & No & Yes, 2 & Yes, 2 & No & No & Yes, 8 & Yes, 4 \\
\hline variables used in instrumentation? & No & No & No & No & No & No & Yes, 2 & Yes, 2 \\
\hline
\end{tabular}

